\title{
Building Climate-Resilient Cotton Production System for Changing Climate Scenarios Using the DSSAT Model
}

\author{
Zoia Arshad Awan ${ }^{1}$, Tasneem Khaliq ${ }^{2}, * \mathbb{C}$, Muhammad Masood Akhtar ${ }^{1}$, Asad Imran ${ }^{1}$, Muhammad Irfan ${ }^{1}$, \\ Muhammad Jarrar Ahmed ${ }^{1}$ and Ashfaq Ahmad ${ }^{2}$ \\ 1 Sustainable Agriculture and Food Programme (SAFP), World Wide Fund for Nature (WWF), \\ Lahore 54000, Pakistan; zaawan@wwf.org.pk (Z.A.A.); makhtar@wwf.org.pk (M.M.A.); \\ aimran@wwf.org.pk (A.I.); mdirfan@wwf.org.pk (M.I.); mjahmed@wwf.org.pk (M.J.A.) \\ 2 Department of Agronomy, University of Agriculture Faisalabad (UAF), Faisalabad 38000, Pakistan; \\ aachattha1@yahoo.com \\ * Correspondence: drtasneem@uaf.edu.pk
}

check for updates

Citation: Arshad Awan, Z.; Khaliq, T.; Masood Akhtar, M.; Imran, A.; Irfan, M.; Jarrar Ahmed, M.; Ahmad, A. Building Climate-Resilient Cotton Production System for Changing Climate Scenarios Using the DSSAT Model. Sustainability 2021, 13, 10495. https://doi.org/10.3390/su131910495

Academic Editor: Aureliano C. Malheiro

Received: 21 May 2021

Accepted: 5 August 2021

Published: 22 September 2021

Publisher's Note: MDPI stays neutral with regard to jurisdictional claims in published maps and institutional affiliations.

Copyright: (c) 2021 by the authors. Licensee MDPI, Basel, Switzerland. This article is an open access article distributed under the terms and conditions of the Creative Commons Attribution (CC BY) license (https:// creativecommons.org/licenses/by/ $4.0 /)$.

\begin{abstract}
Cotton production is highly vulnerable to climate change, and heat stress is a major constraint in the cotton zone of Punjab, Pakistan. Adaptation is perceived as a critical step to deal with forecasted and unexpected climatic conditions. The objective of this study was to standardize and authenticate a cotton crop model based on climate and crop husbandry data in order to develop an adaptation package for cotton crop production in the wake of climate change. For the study, the data were collected from the cotton-growing areas of Punjab, viz. Bahawalpur and Khanewal. After the calibration and validation against field data, the Cropping System Model CSM-CROPGROCotton in the shell of the decision support system for agro-technology transfer (DSSAT) was run with a future climate generated under two representative concentrations pathways (RCPs), viz. RCPs 4.5 and 8.5 with five global circulation models (GCMs). The whole study showed that a model is an artistic tool for examining the temporal variation in cotton and determining the potential impact of planting dates on crop growth, phenology, and yield. The results showed that the future climate would have drastic effects on cotton production in the project area. Reduction in seed cotton yield (SCY) was $25.7 \%$ and $32.2 \%$ under RCPs 4.5 and 8.5 , respectively. The comparison of five GCMs showed that a hot/wet climate would be more damaging than other scenarios. The simulations with different production options showed that a $10 \%$ and $5 \%$ increase in nitrogen and plant population, respectively, compared to the present would be the best strategy in the future. The model further suggested that planting conducted 15 days earlier, combined with the use of water and nitrogen (fertigation), would help to improve yield with $10 \%$ less water under the future climate. Overall, the proposed adaptation package would help to recover $33 \%$ and $37 \%$ of damages in SCY due to the climate change scenarios of RCP 4.5 and 8.5 , respectively. Furthermore, the proposed package would also help the farmers increase crop yield by $7.5 \%$ over baseline (current) yield.
\end{abstract}

Keywords: adaptation package; cotton production; climate change; climate-resilient; DSSAT model

\section{Introduction}

Agriculture is highly dependent on climate and, therefore, climate change could have major effects on crop yields and thus food and fiber supply. It is predicted that the global temperature is expected to increase by $2.9^{\circ} \mathrm{C}$ to $5.5^{\circ} \mathrm{C}$ by 2060 , ultimately causing a considerable reduction in crop production [1]. It is anticipated that the adverse impacts of climate change on the agricultural sector will exacerbate the incidence of rural poverty. The impacts on poverty are likely to be especially severe in developing countries such as Pakistan, where the agricultural sector is an important source of livelihood for a majority of the rural farming community. The impacts of climate change for Pakistan's farmers are likely to be problematic for the food security of many rural households. Pakistan is expected to be one of the countries most affected by climate change in South Asia [2]. As 
climate change is a threat to water resources, it also imperils the production of food and fiber [3]. Hence, in Pakistan, the cotton crop has faced several challenges such as climatic change, weather variability, pests and diseases attack, and price volatility. Ever-increasing temperature contributes to high evapotranspiration, resulting in reduced crop growth and productivity under water stress. The cotton production in Punjab and Sindh is subjected to low seasonal precipitation and elevated temperatures. Thus, the influence of elevated variations in precipitation from the mean value adversely affects cotton productivity [4].

The livelihood of millions of farmers and industrial laborers depends upon the cotton economy in Pakistan. The cotton crop is grown irrigated to semiarid, mostly in low rainfall and high-temperature conditions, and is tolerant to high temperature and water stress to some extent due to its vertical tap root system [5]. The historical experience, however, shows that heat stress is a major restraint on the production of cotton in various countries, including Pakistan, India, and Syria. Unfortunately, Pakistan falls into this category; a further temperature rise could damage its cotton economy [6]. Therefore, an understanding of the cotton-climate relationship is important for their welfare. Projections suggest that there will be an increase in the temperature (minimum: $2.5^{\circ} \mathrm{C}$ and $3.6^{\circ} \mathrm{C}$; maximum: $2.7^{\circ} \mathrm{C}$ and $3.8^{\circ} \mathrm{C}$ ) under 4.5 and $8.5 \mathrm{RCPs}$, respectively, from 2040-2069 in the cotton area of Punjab, Pakistan. Likewise, a decrease in rainfall would be about $33 \%$ and $52 \%$ during the cotton growing season under 4.5 and $8.5 \mathrm{RCPs}$, respectively, for the mid-century (2040-2069) with a hot/dry general circulation model (GCM) [7,8]. Most of the researchers found that climate change and inefficient cotton production management practices have reduced the yield of cotton in Pakistan [9-12].

It is worth examining the effects of climate change on all agro-ecological areas for future adaptations to national climatic conditions. To assess the direct and indirect effects of the climate on yield at the farm, regional, or higher levels requires integrated models that consider system interactions. For this, different climate adaptation approaches should be organized in association with other science disciplines, support services stakeholder's engagement, and extensions for cotton crop. Crop growth simulation models (CGSMs) are considered valuable tools and have been used in the tactical and strategic decision support for crop productivity enhancement [13]. Crop models such as Cropping System Models (CSM) and Decision Support Systems for Agro-technology Transfer (DSSAT) can study cotton crop management, crop improvement, genotype, water management, and climate impact studies on cotton production [14-18]. Previous studies reported that these models are also used in studies of climate risk management and for enhancing the resilience in crops and cropping systems $[8,19,20]$. The DSSAT is a software application program that is comprised of crop simulation models for over 42 crops (as of Version 4.7.5). The tools include database management programs for soil, weather, and crop management, as well as experimental data, application, and utility programs to facilitate the effective use of the models. The crop simulation models simulate growth, development, and yield as a function of the soil-plant-atmosphere dynamics [21,22]. DSSAT and its crop simulation models have been used for a wide range of applications at different spatial and temporal scales. This includes regional assessments of the impact of climate variability and climate change, on-farm precision management, water use, greenhouse gas emissions, and longterm sustainability through soil organic carbon and nitrogen $(\mathrm{N})$ balances [22]. DSSAT offers information with which the users can rapidly appraise new crops, products, and practices for adoption. The Cropping System Model (CSM)-Crop Growth (CROPGRO)Cotton in the shell of DSSAT can be used to guide cotton farmers to make crop management decisions to optimize the use of limited available resources and lessen the risks associated with the environment $[5,11,15]$. Previously, the model was also used in water and irrigation use efficiency distribution studies [23].

Keeping the above situation in view, this study was planned to (i) test the model performance for simulating the effects of different agronomic options on crop growth and yield, (ii) study the impacts of climate change on cotton yield in the project area, and 
(iii) develop an adaptation package for cotton crops in the wake of climate change using a crop simulation model such as DSSAT.

\section{Materials and Methods}

\subsection{The Project Area}

Two districts of Punjab, Bahawalpur and Khanewal, were selected due to them possessing large areas under cotton cultivation and a high agricultural vulnerability to climate change $[10,11]$. Field surveys were conducted by the World Wide Fund for Nature (WWF)Pakistan in the project area of Bahawalpur and Khanewal regarding cotton crop husbandry.

\subsection{Collection of Field Survey Data}

The primary data were collected and assessed in this study. Before the data collection, the field facilitators (FFs) were trained to conduct the preliminary survey. For primary data, the farmers in the studied area were interviewed through well-structured and comprehensive questionnaires to gather the data of the farmers' adoptive practices for cotton cultivation. For secondary data, the Soil Survey of Pakistan (SSOP) and the Pakistan Meteorological Department (PMD) were contacted.

\subsection{Experimental Site}

The experiment was conducted at the agronomic research area of the University of Agriculture, Faisalabad using RCBD with three replications $(n=3)$ during the year 2019. Two factors were studied in the experiment: the sowing date (22 April, 7 May, and 22 May) in main plots and the cotton cultivars (NIAB-878, FH-Lalazar, and BS-15) in the subplot. The size of every trial unit was $4.5 \mathrm{~m} \times 8 \mathrm{~m}$, keeping the row-row distance at 75 $\mathrm{cm}$ or the plant-plant distance at $22.5 \mathrm{~cm}$. The experimental site was ploughed with the disc harrow and then with one application of the rotavator to make the soil porous, followed by two cultivations and planking. After this, the seedbed was prepared with the help of a bed-shaper. The seed was sown using the choppa method at a rate of $20 \mathrm{~kg} \mathrm{ha}^{-1}$. After seed sowing, a combination of pre-emergence herbicides, S-metolachlor and pendimethalin (@ $900 \mathrm{~mL}$ acre ${ }^{-1}$ ), were applied to overcome the infestation of weeds. The irrigation scheduling was done according to the recommendations of the Punjab Agriculture Department. After sowing, low irrigation was applied immediately to get better germination. After four days, interval irrigation was conducted to ensure good emergence. Subsequent other irrigations were applied at an interval of fifteen days throughout crop duration. Nitrogen $(\mathrm{N})$, phosphorus $(\mathrm{P})$, and potassium $(\mathrm{K})$ fertilizers were applied at a rate of 150:125:100 kg ha ${ }^{-1}$, respectively, whereas nitrogen application was done in three equal split doses. The phosphorus and potassium, along with one split of nitrogen, were applied at the time of sowing while the remaining nitrogen splits were side dressed at the time of square formation and flowering. For all of the treatments, all other agronomic operations such as inter-culture operations and disease and insect pest control were kept regular and uniform. Data on crop phenology, growth, radiation use efficiency, and SCY were collected.

\subsection{Crop Modeling}

The Decision Support System for Agrotechnology Transfer (DSSAT) is a software application program comprised of crop simulation models for over 42 crops (as of Version 4.7.5) as well as tools to facilitate the effective use of the models. The tools include database management programs for soil, weather, crop management and experimental data, utilities, and application programs. The crop simulation models simulate growth, development, and yield as a function of the soil-plant-atmosphere dynamics [13-15].

In the current study, the CSM-CROPGRO-Cotton model in the shell of DSSAT [24,25] was used to study the impact of climate change on cotton performance. Furthermore, this model was also used to optimize the production options such as the sowing date, variety selection, plant population, fertilizer rate, and irrigation requirement for developing an adaptation package to enhance climate resilience in cotton in Bahawalpur and Khanewal. 
Calibration is a process of adjusting some model parameters to the local conditions. It is also necessary for getting genetic coefficients for new cultivars used in the modeling study. The model was calibrated with the experimental data that included phenology, biomass, LAI, and yield components. The model calibration was started to optimize the most important parameters in soil and genotype files under the non-limiting conditions of irrigation and nitrogen to obtain the crop coefficients potential, which improves the simulations. The soil parameters were adjusted for the best simulation of soil moisture and fertility. It included the soil fertility factor (SLPF), the soil root growth factor (SRGF) (as cotton is a deep-rooted crop), and the drained upper limit (SDUL) of each layer. The SLPF was adjusted before the genetic cultivar coefficients calibration, as it affects the overall crop growth and cottonseed yield and the simulation with a suitable SLPF would be expected to be close to the recorded observation. The simulated cottonseed yield was compared with the observation of all experimental treatments for the adjustment of the SLPF with the lowest root mean square error (RMSE) and a higher index of agreement (d-statistic). Finally, cultivar coefficients were estimated for each variety (Table 1). Cultivar coefficients were determined successively starting from the coefficients dealing with the vegetative growth and phenology of the plant followed by those described by SCY against the best-performing sowing date. To select the most suitable set of coefficients, the iterative approach proposed by Hunt et al. was employed [26].

Table 1. Genetic Coefficients of different cultivars estimated during the calibration of the model.

\begin{tabular}{|c|c|c|c|c|c|c|c|c|c|c|c|c|}
\hline \multirow{2}{*}{ Parameters } & \multicolumn{10}{|c|}{ Calibrated Value } & \multirow{2}{*}{$\begin{array}{l}\text { Testing } \\
\text { Range }\end{array}$} & \multirow{2}{*}{$\begin{array}{c}\text { Default } \\
\text { Value }\end{array}$} \\
\hline & $\begin{array}{c}\text { NIAB- } \\
878\end{array}$ & $\begin{array}{c}\text { FH- } \\
\text { Lalazar }\end{array}$ & BS-15 & $\begin{array}{c}\text { IUB- } \\
13\end{array}$ & Mubarak & $\begin{array}{l}\text { GH- } \\
\text { Uhad }\end{array}$ & Debal & $\begin{array}{c}\text { Cyto- } \\
179\end{array}$ & $\begin{array}{l}\text { NIAB- } \\
\text { Kiran }\end{array}$ & $\begin{array}{l}\text { CIM- } \\
313\end{array}$ & & \\
\hline \multicolumn{13}{|c|}{ Development } \\
\hline FL-EM & 5 & 5 & 5 & 5 & 5 & 5 & 5 & 5 & 5 & 5 & 3-9 & 4 \\
\hline EM-FL & 46 & 45 & 40 & 42 & 43 & 44 & 43 & 44 & 46 & 43 & 35 to 50 & 38 \\
\hline FL-SH & 11 & 13 & 12 & 15 & 16 & 14 & 15 & 16 & 12 & 14 & 05-20 & 12 \\
\hline FL-SD & 24 & 25 & 28 & 30 & 26 & 20 & 21 & 26 & 22 & 27 & $10-30$ & 15 \\
\hline SD-PM & 48 & 49 & 48 & 50 & 52 & 46 & 45 & 51 & 43 & 45 & $30-60$ & 42 \\
\hline FL-LF & 68 & 70 & 72 & 69 & 70 & 69 & 71 & 66 & 65 & 73 & $35-80$ & 75 \\
\hline \multicolumn{13}{|c|}{ Growth } \\
\hline LFMAX & 1.45 & 1.50 & 1.13 & 1.15 & 1.42 & 1.52 & 1.37 & 1.34 & 1.48 & 1.47 & $0.5-2.0$ & 1.1 \\
\hline SLAVR & 139 & 155 & 150 & 145 & 165 & 163 & 140 & 145 & 142 & 160 & $100-250$ & 170 \\
\hline SIZLF & 275 & 305 & 300 & 280 & 320 & 315 & 305 & 285 & 290 & 310 & $200-400$ & 300 \\
\hline \multicolumn{13}{|c|}{ Yield } \\
\hline XFRT & 0.65 & 0.63 & 0.69 & 0.70 & 0.61 & 0.67 & 0.60 & 0.65 & 0.67 & 0.64 & $0.50-0.90$ & 0.85 \\
\hline SFDUR & 31 & 35 & 32 & 33 & 30 & 34 & 36 & 30 & 32 & 35 & $15-40$ & 24 \\
\hline PODUR & 14.0 & 13.0 & 14.5 & 13.5 & 14.0 & 15.0 & 15.5 & 14.5 & 13.5 & 13 & 5-20 & 8 \\
\hline THRSH & 65 & 68 & 63 & 70 & 71 & 73 & 69 & 72 & 70 & 72 & $40-90$ & 70 \\
\hline
\end{tabular}

PL-EM: Thermal time between planting and emergence, EM-FL: Photothermal time between plant emergence and flower appearance, FL-SH: Photothermal time between first flower and first boll, FL-SD: Photothermal time between first flower and first seed, SD-PM: Photothermal time between first seed and physiological maturity, FL-LF: Photothermal time between first flower and the end of leaf expansion, LFMAX: Maximum leaf photosynthesis rate at $30^{\circ} \mathrm{C}, 350 \mathrm{ppm} \mathrm{CO}_{2}$, and high light $\left(\mathrm{mg} \mathrm{CO}_{2} \mathrm{~m}^{-2} \mathrm{~S}^{-1}\right)$, SLAVR: Specific leaf area of cultivar under standard growth conditions $\left(\mathrm{cm}^{-2} \mathrm{~g}^{-1}\right)$, SIZLF: Maximum size of the full leaf $\left(\mathrm{cm}^{2}\right)$, XFRT: Maximum fraction of daily growth that is partitioned to seed + shell, SFDUR: Seed filling duration for pod cohort at standard growth conditions, PODUR: Time required for cultivar to reach final boll load under optimal conditions, THRSH The maximum ratio of (seed/(seed + shell)) at maturity.

To check the accuracy of the model simulations, it was run with data recorded against the remaining two sowing date treatments. The model was further validated with data collected during field surveys and experiments conducted by WWF-Pakistan in the project area (i.e., Bahawalpur and Khanewal), and the field information regarding crop husbandry was used as input data for the model. The genetic coefficients for other varieties found in the field were also estimated using this field survey data. Simulation performance was evaluated by calculating different statistic indices like RMSE [27] and mean percentage difference (MPD) across all locations. For individual sowing, the date error (\%) between simulated and observed grain yield was calculated. The time course simulation of crop 
biomass and LAI was assessed by d-statistics, an aggregate overall indicator [28]. These measurements were calculated as

$$
\begin{gathered}
\text { RMSE }=\left[\sum_{i=1}^{n} \frac{\left(P_{i}-O_{i}\right)^{2}}{n}\right]^{0.5} \\
\text { MPD }=\left[\sum_{i=1}^{n}\left(\frac{\left|\mathrm{O}_{i}-P_{i}\right|}{O_{i}}\right) 100\right] / n \\
\text { Error }(\%)=\left[\frac{(P-O)}{O}\right] 100 \\
d=1-\left[\frac{\sum_{i-1}^{n}\left(P_{i}-O_{i}\right)^{2}}{\sum_{i=1}^{n}\left(\left|P_{i}{ }^{\prime}\right|+\left|\mathrm{O}_{i}{ }^{\prime}\right|\right)^{2}}\right]
\end{gathered}
$$

where $\mathrm{P}_{\mathrm{i}}$ and $\mathrm{O}_{\mathrm{i}}$ are the predicted and observed values for studied variables, respectively, and $\mathrm{n}$ is the number of observations. A linear regression analysis between the observed and simulated grain yield and biomass at harvest was done to evaluate the performance of the model at different locations. Model performance improved as $\mathrm{R}^{2}$ and $\mathrm{d}$-index value approached unity, while RMSE, MPD, and error proceeded to zero.

\subsection{Soil and Weather Data for Model}

The Lyallpur soil series was used for Faisalabad during the calibration of the model with experimental data. The data relating to the soil series of each location (Bahawalpur and Khanewal) were collected from the SSOP (Table 2). The soil profile data of the sand, silt, clay, organic carbon (OC \%), $\mathrm{pH}$ in water, cation exchange capacity $\left(\mathrm{cmol} \mathrm{kg}^{-1}\right)$, and total nitrogen \% were collected and used as input for the model. The organic carbon percentage was computed by dividing the value of organic matter by 1.70 . The parameters such as bulk density $\left(\mathrm{gcm}^{-3}\right)$, permanent wilting point $(\%)$, and field capacity (\%) were calculated by the model using the methods described by Rawls et al. [29].

Table 2. Characteristics of the dominant soil series of the project area.

\begin{tabular}{ccc}
\hline District & Soil Series & Characteristics \\
\hline $\begin{array}{c}\text { Bahawalpur } \\
\left(29^{\circ} 25^{\prime} \mathrm{N} \text { and } 71^{\circ} 40^{\prime} \mathrm{E}\right)\end{array}$ & Bijnot & Fine sands \\
\hline & Thar & Fine sands \\
\cline { 2 - 3 } & Maruwala & Loamy fine sands. \\
\hline $\begin{array}{c}\text { Khanewal } \\
\left(30^{\circ} 17^{\prime} \mathrm{N} \text { and } 71^{\circ} 55^{\prime} \mathrm{E}\right)\end{array}$ & Miani & Silty clay loams \\
\hline & Nabipur & Loams \\
\hline & Sultanpur & Silt loams and very fine sandy loams \\
\hline
\end{tabular}

The daily maximum temperature (Tmax), minimum temperature (Tmin), and rainfall and sunshine hours for the cropping season (2019) were also collected (Figure 1a,b). The solar radiations were calculated using the Angstrom formula (Angstrom 1924). These data were also used as the input data set in model simulations. 


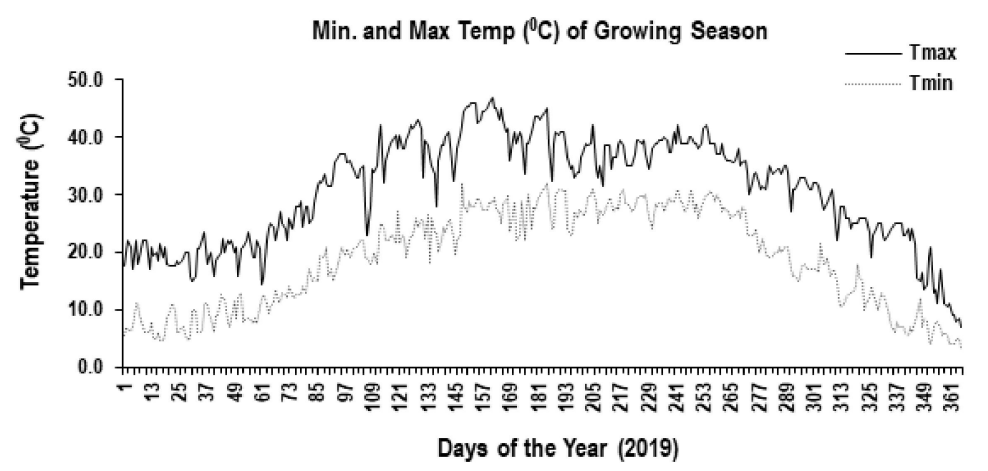

(a)

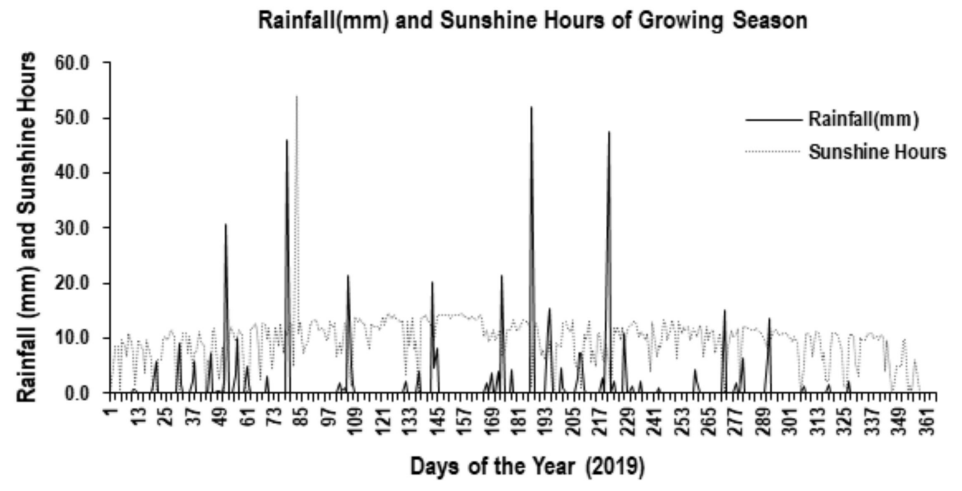

(b)

Figure 1. (a) Minimum and Maximum Temperature $\left({ }^{\circ} \mathrm{C}\right)$ recorded during 2019. (b) Rainfall and Sunshine hour trends during 2019.

\subsection{Statistical Downscaling and Climate Change Projections}

Baseline climate data (1989-2019) for daily Tmax, Tmin, solar radiations and rainfall were obtained from the PMD. The climate change scenarios were generated for mid-century (2039-2069) under RCP 8.5. It was assumed that global annual greenhouse gas emissions continue to rise throughout the twenty-first century using the delta method approach. Five General Circulation Models (GCMs) were used for simulating the climate systems in response to climate change factors, e.g., greenhouse gasses (Table 3) and for representing the uncertainty of the prediction of the temperatures and precipitation for all locations from the Coupled Model Inter-comparison Project (CMIP5) [30]. In GCM simulations, the shape parameters of the gamma distribution for a wet event are not of sufficient quality; therefore, mean monthly changes were imposed to the baseline climate using a stretch distribution approach [31]. Parameters such as solar radiation and humidity were assumed to be unchanged during this process. Finally, cool/wet, cool/dry, hot/wet, hot/dry, and middle climate scenarios were developed for the GCMs. Rosenzweig et al. [32] described the detailed protocol.

Table 3. Detail of the General Circulation Models (GCMs) used in climate change scenario development.

\begin{tabular}{cc}
\hline GCMs Names & Categories \\
\hline GFDL-CM3_1 & Hotwet \\
BNU-ESM & Middle \\
CCSM4_E & Cooldry \\
INMCM4 & Coolwet \\
CMCC-CMS_W & Hotdry \\
\hline
\end{tabular}




\subsection{Climate Change Impact Assessment}

A seasonal analysis tool in the shell of DSSAT was used to evaluate the impact of climate change on cotton for mid-century scenarios as predicted by the Pakistan Meteorological Department through the Geophysical Fluid Dynamics Laboratory Climate Model 3 (GFDL-CM3) model. Seasonal files were created from the management practices of optimum sowing dates for both locations. The baseline climate (1989-2019) and future scenarios generated by the GFDL-CM3 model were used to create the weather files for each location. The Carbon dioxide $\left(\mathrm{CO}_{2}\right)$ concentration of $571 \mathrm{ppm}$ was used for RCP 8.5 under the mid-century, as proposed by IPCC (2013). The impact of climate change was calculated from the future and baseline to the mean yield using the following equation.

$$
\% \text { Change }=\{(\text { Simulated }- \text { Observed }) / \text { Obesrved }\} \times 100
$$

The accuracy and precision of the model simulations were further evaluated by running the model with data collected against the remaining treatments (7 May and 22 May). The surveyed data, including the crop husbandry practices of farmers in the project area (Bahawalpur and Khanewal), were used as the input data set, and the model was validated to assess its accuracy at the farmer field.

\subsection{Climate Change Scenario Generations}

Climate change projections for the region were generated using the output of the five GCMs from the latest CMIP5 family under RCP 4.5 and RCP 8.5 scenarios $\left(\mathrm{CO}_{2}\right.$ concentration at $571 \mathrm{ppm}$ ). A major indication of climate change in the target region complies with the global trend of positive increases in both maximum and minimum temperature. However, there are highly heterogeneous change patterns observed in the precipitation regime owing to the high inter-annual variability in the region. The integrated assessment of the target region is projected with the temperature changes to be highest under GCMs with hot/wet and hot/dry characteristics. For the cotton season, the highest of the changes were projected in a hot/wet climate with a $3.6^{\circ} \mathrm{C}\left(3.5^{\circ} \mathrm{C}\right)$ increase in minimum temperature and a $4.3^{\circ} \mathrm{C}\left(3.8^{\circ} \mathrm{C}\right)$ increase in maximum temperature (Table 4). Available observed data and generated future data were used for developing the weather files in DSSAT. The simulations were compared with the observed data to study the impact of climate change on cotton productivity in the project area.

Table 4. Integrated Climate Change Projections (2040-2069) for Hot/Dry Conditions in the project area.

\begin{tabular}{ccc}
\hline Variables & Scenarios & Cotton \\
\hline \multirow{2}{*}{$\Delta \operatorname{Tmax}\left({ }^{\circ} \mathrm{C}\right)$} & RCP 4.5 & 2.4 \\
& RCP 8.5 & 3.5 \\
\hline \multirow{2}{*}{$\Delta \operatorname{Tmin}\left({ }^{\circ} \mathrm{C}\right)$} & RCP 4.5 & 2.7 \\
& RCP 8.5 & 3.8 \\
\hline \multirow{2}{*}{$\Delta$ Rain $(\%)$} & RCP 4.5 & -33.1 \\
& RCP 8.5 & -51.7 \\
\hline
\end{tabular}

Note: Tmax = maximum temperature; Tmin = minimum temperature; $\mathrm{RCP}$ = representative concentration pathway

\subsection{Adaptation Strategies for Climate-Resilient Cotton Production}

Adaptation strategies were developed by modifying the crop management practices in the model to cope with possible climate change. The values showing the maximum increase in yield under the mid-century scenarios of RCP 8.5 for both locations were considered as the adaptation strategies for climate-resilient cotton production in the project area. The selected adaptation strategies were variety selection, optimization of planting density, change in planting time, optimization of the amount of nitrogen, and irrigational water (Figure 2). The model was tested against the set of different values/practices and the best combination was selected for maximizing the crop yield under changing climates. 


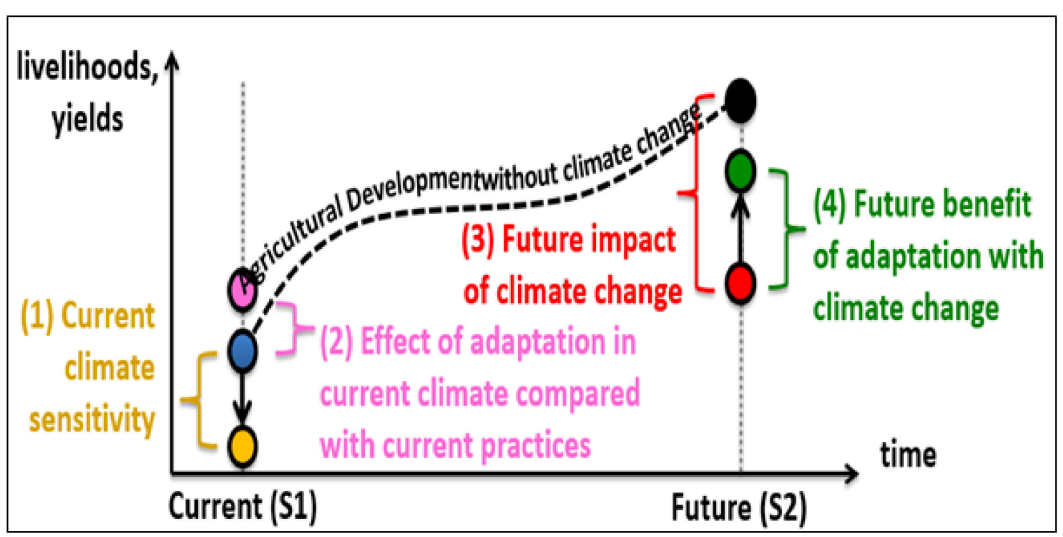

Figure 2. Pictorial view of the methodology of the climate change impact assessment and adaptations for sustainable crop yield in the future.

\section{Results}

\subsection{Soil and Weather Data}

The geographical coordinates and characteristics of the dominant soil series found in the project area were given in Table 2. This data was used to simulate the cotton yield at the farmer level in the project area using the farmer's crop husbandry practices as the input data set for the model. Likewise, mean monthly changes in the mean Tmax, Tmin, and precipitation were calculated and compared with the future 30-year climate to baseline. After that, monthly changes in the standard deviation (SD) of Tmax, SD of Tmin, and rainy days $(>0.1 \mathrm{~mm})$ were calculated and compared with the future climate to baseline (Table 4 ).

\subsection{Parameterization and Calibration with Experimental Data}

The calibration results in Table 5 revealed that the error percentage between the observed and simulated days to anthesis for NIAB-878, FH-Lalazaa, and BS-15 was 1.67\%, as the model predicted. The calibration results regarding physiological maturity with -1.08 , -1.08 , and -1.08 error percentages were compared to the observed days in NIAB-878, FH-Lalazaar, and BS-15, respectively. In LAI, the results indicated that error percentage differences of $-1.92,-3.39$, and -5.39 were calculated in NIAB-878, FH-Lalazaar, and BS-15, respectively. In NIAB-878 for TDM, a $260 \mathrm{~kg} \mathrm{ha}^{-1}$ difference was calculated with an error percentage of 1.95, and FH-Lalazaar was calibrated with an error percent of 7.08. The difference in TDM for BS-15 was calculated with an error percentage of 5.44, whereas the average percentage difference of 4.82 was calculated in all cultivars collectively for TDM. The observed and simulated SCY was $3159.72 \mathrm{~kg} \mathrm{ha}^{-1}$ and $3209 \mathrm{~kg} \mathrm{ha}^{-1}, 2942.77 \mathrm{~kg} \mathrm{ha}^{-1}$ and $3058 \mathrm{~kg} \mathrm{ha}^{-1}, 2984.16 \mathrm{~kg} \mathrm{ha}^{-1}$, and $3125 \mathrm{~kg} \mathrm{ha}^{-1}$ for NIAB-878, FH-Lalazaar, and BS-15, with an average percentage difference of 3.40. These results were reliable enough to evaluate the model against other treatments. The comparison of the time courses TDM (Figure 3) and LAI (Figure 4) also showed that the model simulates the growth pattern of cotton in a good manner. 
Table 5. Comparison of the observed and simulated results during the calibration of the model for cotton cultivars (NIAB-878, FH-Lalazar, and BS-15) on a sowing date of 22 April.

\begin{tabular}{ccccccccccccc}
\hline \multirow{2}{*}{ Parameters } & \multicolumn{3}{c}{ NIAB-878 } & \multicolumn{3}{c}{ FH-Lalazar } & & \multicolumn{2}{c}{ BS-15 } & \multicolumn{3}{c}{ Average } \\
\cline { 2 - 13 } & Obs. & Sim. & Error \% & Obs. & Sim. & Error \% & Obs. & Sim. & Error \% & Obs. & Sim. & Error \% \\
\hline $\begin{array}{c}\text { Days to } \\
\text { Anthesis }\end{array}$ & 60 & 61 & 1.67 & 60 & 61 & 1.67 & 60 & 61 & 1.67 & 60 & 61 & 1.67 \\
\hline $\begin{array}{c}\text { Days to } \\
\text { physiological } \\
\text { maturity }\end{array}$ & 186 & 184 & -1.08 & 186 & 184 & -1.08 & 186 & 184 & -1.08 & 186 & 184 & -1.08 \\
\hline LAI & 5.74 & 5.63 & -1.92 & 5.02 & 4.85 & -3.39 & 5.19 & 4.91 & -5.39 & 5.32 & 5.13 & -3.57 \\
\hline $\begin{array}{c}\text { TDM } \\
\left(\mathrm{kg} \mathrm{ha}^{-1}\right)\end{array}$ & 13,309 & 13,568 & 1.95 & 11,493 & 12,306 & 7.08 & 11,854 & 12,501 & 5.44 & 12,218 & 12,792 & 4.82 \\
\hline SCY $\left(\mathrm{kg} \mathrm{ha}^{-1}\right)$ & 3160 & 3209 & 1.56 & 2943 & 3058 & 3.92 & 2984 & 3125 & 4.72 & 3029 & 3131 & 3.40 \\
\hline
\end{tabular}

Note: Obs. = observed; Sim. = simulated; LAI = leaf area index; SCY = seed cotton yield.

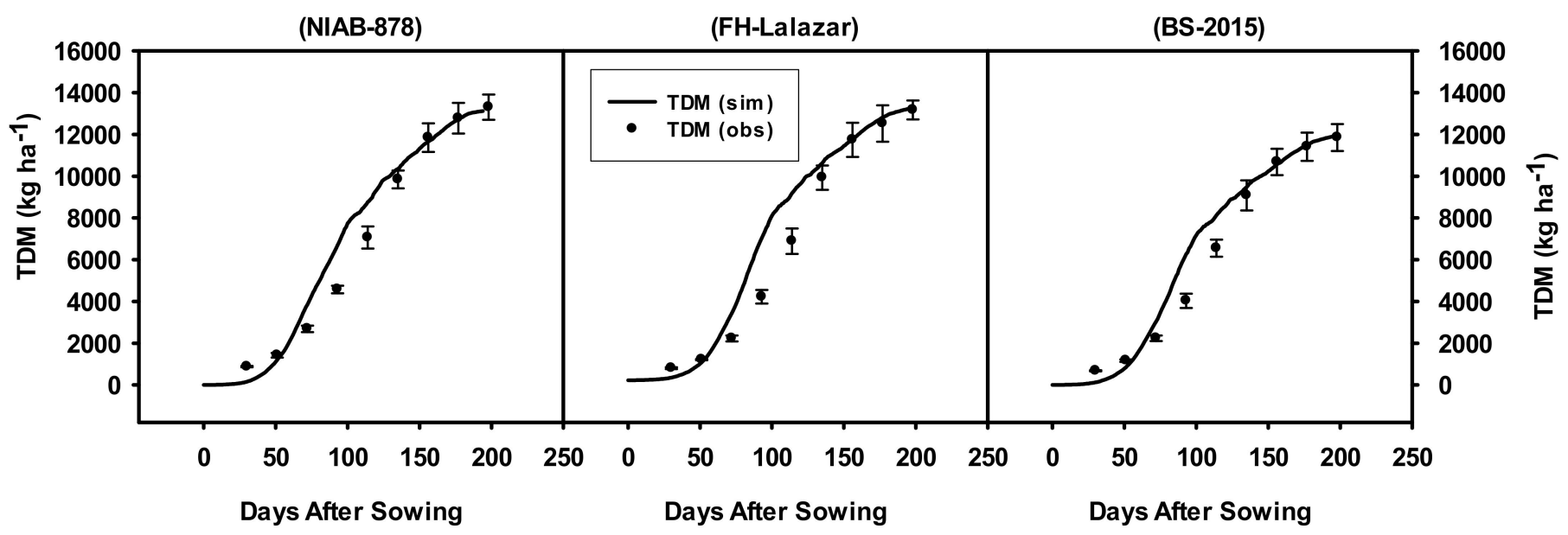

Figure 3. Comparison of the observed and simulated TDM of cotton cultivars (NIAB-878, FH-Lalazaar and BS-15) during calibration with a sowing date of 22 April 2019.

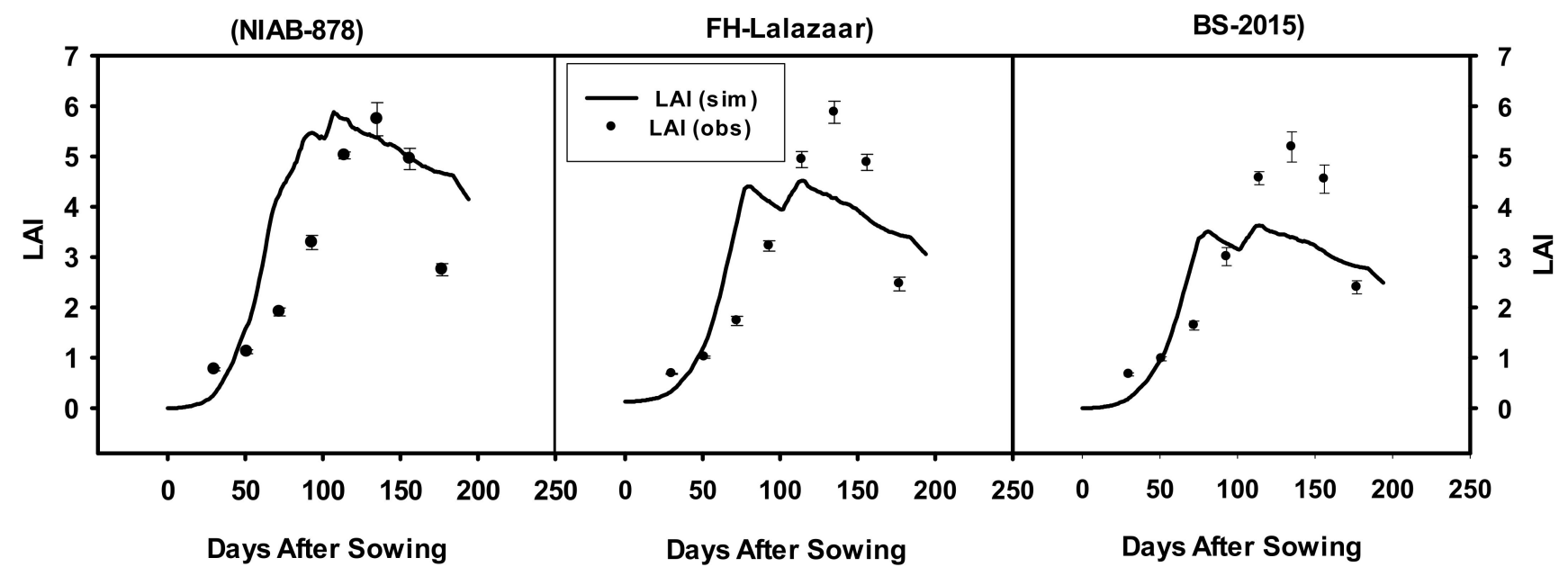

Figure 4. Comparison of the observed and simulated LAI of cotton cultivars (NIAB-878, FH-Lalazaar and BS-15) during calibration with a sowing date of 22 April 2019. 


\subsection{Evaluation of the Model with Experimental Data}

The accuracy and precision of the model simulations were further evaluated by running the model with data collected against the remaining treatments (7 May and 22 May). The following parameters were compared:

\subsubsection{Days to Anthesis}

The model evaluation results indicated that the days to anthesis were in the range of good accuracy with a mean error of $9.87 \%$. Table 6 shows the observed and simulated values of days to anthesis for two sowing dates (7 May and 22 May) in three different cotton varieties (NIAB-878, FH-Lalazaar, and BS-15). For NIAB-878, the error difference was $5.36 \%$ and $12 \%$ on both sowing dates. In the case of FH-Lalazaar, the model evaluated days to anthesis quite well. The error differences in FH-Lalazaar for the anthesis were $7.27 \%$ and $14.29 \%$ for the second and third sowings. For FH-142, the evaluation results for various sowing dates were also satisfactory. The difference in days to anthesis was calculated at $7.27 \%$ in the second and third sowings. The d-index, RMSE and mean percent difference (MPD) were calculated with the values of $0.58,5.4$, and $10.08 \%$, respectively. The deviation in growing climatic conditions for the different cotton varieties in different sowing windows might be responsible for the different phenological (flower initiation) responses.

Table 6. Comparison of the observed and simulated days to anthesis and the physiological maturity of the different cotton cultivars at different sowing dates.

\begin{tabular}{ccccccc}
\hline \multirow{2}{*}{ Treatments } & \multicolumn{3}{c}{ Days to Anthesis } & \multicolumn{3}{c}{ Days to Physiological Maturity } \\
\cline { 2 - 7 } & Obs. & Sim. & Error (\%) & Obs. & Sim. & Error (\%) \\
\hline $\mathrm{S}_{2} \mathrm{~V}_{1}$ & 56 & 59 & 5.36 & 173 & 180 & 4.05 \\
$\mathrm{~S}_{2} \mathrm{~V}_{2}$ & 55 & 59 & 7.27 & 173 & 180 & 4.05 \\
$\mathrm{~S}_{2} \mathrm{~V}_{3}$ & 55 & 59 & 7.27 & 173 & 180 & 4.05 \\
$\mathrm{~S}_{3} \mathrm{~V}_{1}$ & 50 & 56 & 12.00 & 161 & 175 & 8.70 \\
$\mathrm{~S}_{3} \mathrm{~V}_{2}$ & 49 & 56 & 14.29 & 161 & 175 & 8.70 \\
$\mathrm{~S}_{3} \mathrm{~V}_{3}$ & 49 & 56 & 14.29 & 161 & 175 & 8.70 \\
\hline Average & 52 & 58 & 9.87 & 167 & 178 & 6.29 \\
\hline D-Index & & 0.58 & & & 0.56 & \\
MPD & 10.08 & & & 6.37 & \\
RMSE & 5.40 & & & 11.07 &
\end{tabular}

Note: $\mathrm{S}_{2}=7$ May; $\mathrm{S}_{3}=22$ May; $\mathrm{V}_{1}=$ NIAB-878; $\mathrm{V}_{2}=$ FH-Lalazaar; $\mathrm{V}_{3}=$ BS 15; Obs. = observed; Sim. = simulated $\mathrm{MPD}=$ mean percent difference; RMSE = root mean square error.

\subsubsection{Days to Physiological Maturity}

The model evaluation results indicated that days to physiological maturity were in the range of good accuracy with a mean error of $6.29 \%$. Table 6 shows the observed and simulated values of days to physiological maturity for two sowing dates (7 May and 22 May) in three different cotton varieties (NIAB-878, FH-Lalazaar, and BS-15). For NIAB-878, a $4.05 \%$ and $8.70 \%$ percent difference was seen after the evaluation for days to physiological maturity after sowing. In the case of FH-Lalazaar, the model evaluated days to physiological maturity after sowing quite well. The error differences in FH-Lalazaar for physiological maturity were $4.05 \%$ and $8.70 \%$ for the second and third sowings. For BS- 15 , the evaluation results for various sowing dates were also satisfactory. The difference in days to physiological maturity was calculated at $4.05 \%$ and $8.70 \%$ in the second and third sowings. The d-index, RMSE and mean percent difference (MPD) were calculated with the values of $0.56,11.07$, and $6.37 \%$ respectively. The deviation in growing climatic conditions in the various seedling ages in different fine cotton varieties might be responsible for the different phenological (boll opening) responses. 


\subsubsection{Leaf Area Index (LAI)}

The model fairly simulated the LAI fairly well, with an average error of $-6.58 \%$. The data in Table 7 shows the RMSE value to be 0.33 , while the value of the D-index among the simulated and observed values was 0.86 and the MPD value was $6.73 \%$. The model evaluation results for NIAB-878 demonstrated that the LAI was simulated with an error difference of $-9.42 \%$ and $12.97 \%$ in the second and third sowings. The error differences of $0.24 \%$ and $-6.45 \%$ were measured in both sowing dates of FH-Lalazar. The evaluation results regarding BS-15 show that the crop model simulated LAI in second and third sowings with estimated error differences of $-0.71 \%$ and $-10.58 \%$.

Table 7. Comparison of the observed and simulated results to SCY, TDM, and LAI of the different cotton cultivars at different sowing dates.

\begin{tabular}{|c|c|c|c|c|c|c|c|c|c|}
\hline \multirow{2}{*}{ Treatments } & \multicolumn{3}{|c|}{ LAI } & \multicolumn{3}{|c|}{ SCY (kg ha $\left.{ }^{-1}\right)$} & \multicolumn{3}{|c|}{ RMSE (kg ha-1) } \\
\hline & Obs. & Sim. & Error $(\%)$ & Obs. & Sim. & Error (\%) & Obs. & Sim. & Error $(\%)$ \\
\hline $\mathrm{S}_{2} \mathrm{~V}_{1}$ & 4.67 & 4.23 & -9.42 & 2824 & 2956 & 4.69 & 11,232 & 11,530 & 2.65 \\
\hline $\mathrm{S}_{2} \mathrm{~V}_{2}$ & 4.12 & 4.13 & 0.24 & 2681 & 2888 & 7.73 & 9731 & 10,988 & 12.92 \\
\hline $\mathrm{S}_{2} \mathrm{~V}_{3}$ & 4.22 & 4.19 & -0.71 & 2753 & 2908 & 5.65 & 10,058 & 11,250 & 11.85 \\
\hline $\mathrm{S}_{3} \mathrm{~V}_{1}$ & 4.01 & 3.49 & -12.97 & 2588 & 2698 & 4.26 & 9352 & 9899 & 5.85 \\
\hline $\mathrm{S}_{3} \mathrm{~V}_{2}$ & 3.41 & 3.19 & -6.45 & 2329 & 2547 & 9.34 & 7738 & 8961 & 15.81 \\
\hline $\mathrm{S}_{3} \mathrm{~V}_{3}$ & 3.59 & 3.21 & -10.58 & 2404 & 2645 & 10.02 & 8299 & 9123 & 9.93 \\
\hline Average & 4.00 & 3.74 & -6.58 & 25,969 & 2773.7 & 6.83 & 9401 & 10,292 & 9.47 \\
\hline D-Index & & 0.86 & & & 0.77 & & & 0.83 & \\
\hline MPD & & 6.73 & & & 6.95 & & & 9.84 & \\
\hline RMSE & & 0.33 & & & 183.53 & & & 963.11 & \\
\hline
\end{tabular}

Note: $\mathrm{S}_{2}=7$ May; $\mathrm{S}_{3}=22$ May; $\mathrm{V}_{1}=$ NIAB-878; $\mathrm{V}_{2}=$ FH-Lalazaar; $\mathrm{V}_{3}=\mathrm{BS}$ 15; Obs. = observed; Sim. = simulated; LAI = leaf area index; $\mathrm{SCY}=$ seed cotton yield; MPD = mean percent difference; RMSE $=$ root mean square error.

\subsubsection{Seed Cotton Yield}

After the calibration, the crop model was evaluated for SCY against two sowing dates (7 May and 22 May) and three cotton genotypes, and the simulated results were quite precise for this agronomic parameter. The model evaluation results regarding SCY for NIAB-878 demonstrated that the model over-simulated with an error difference of $4.69 \%$ and $4.26 \%$ in the second and third sowing dates, respectively. Furthermore, the mean error difference was $6.28 \%$, collectively, in all sowing dates. The SCY simulation for FH-Lalazaar was also quite satisfactory. Error differences of $7.73 \%$ and $9.34 \%$ were measured in both of the sowing dates of FH-Lalazaar (Table 7). The evaluation results regarding BS-15 showed that the crop model over simulated SCY with an error percent of $5.65 \%$ and $10.02 \%$ for the second and third sowings, whereas the mean value of error difference was $6.82 \%$ for all the treatments. The statistical indices were calculated. The root mean square (RMSE) value was $183.53 \mathrm{~kg} \mathrm{ha}^{-1}$ with a mean percent difference (MPD) of $6.95 \%$, and the d-index value was 0.77 (Table 7). The comparison of time courses TDM and LAI also showed that the model simulates the growth pattern of cotton in a good manner (Figures 5 and 6). 


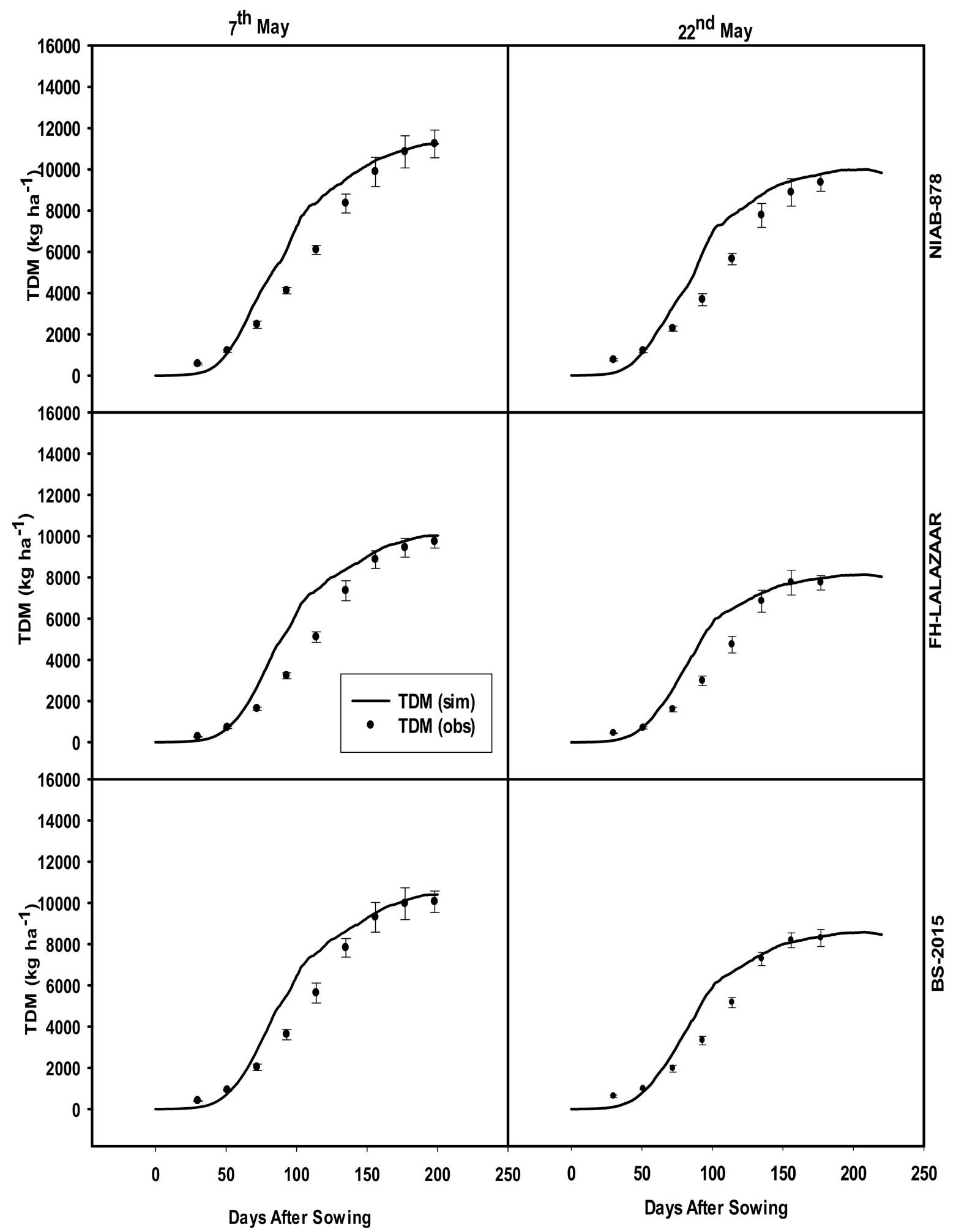

Figure 5. Comparison of the observed and simulated TDM of cotton cultivars (NIAB-878, FH-Lalazaar and BS-15) at different sowing dates (7th and 22nd May) during the evaluation of the model. 


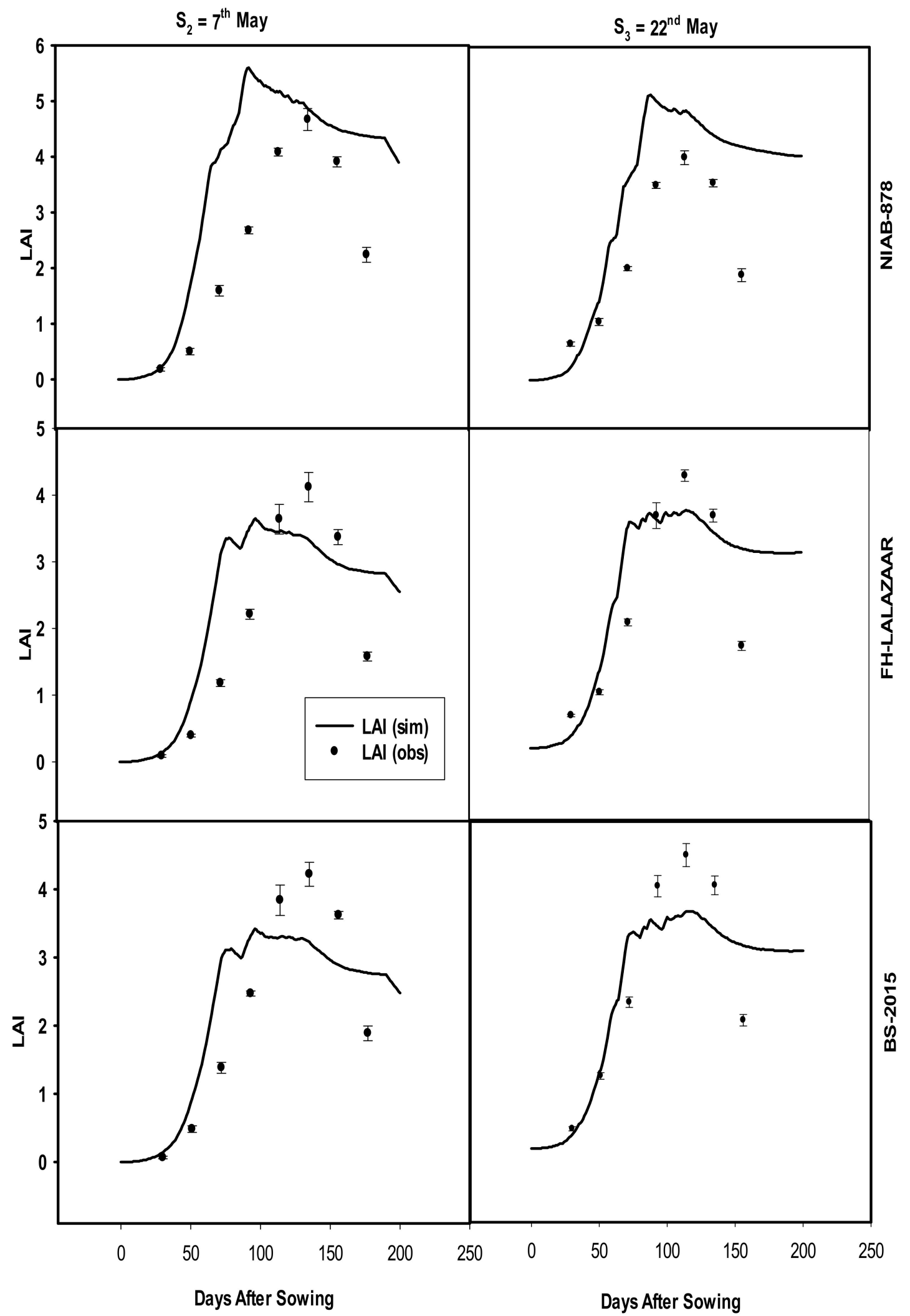

Figure 6. Comparison of the observed and simulated LAI of cotton cultivars (NIAB-878, FH-Lalazaar and BS-15) at different sowing dates (7th and 22nd May) during the evaluation of the model. 


\subsubsection{Total Dry Matter}

The above-ground biomass of the two sowing dates (7 May and 22 May) and three cotton cultivars were evaluated, and the simulated results were quite accurate for this agronomic parameter. The model evaluation results for NIAB- 878 demonstrated that aboveground biomass was simulated with an error difference of $2.65 \%$ and $5.85 \%$ in the second and third sowings. The RMSE simulation for FH-Lalazaar was also quite satisfactory. Error differences of $12.92 \%$ and $15.81 \%$ were measured in both sowing dates of FH-Lalazaar (Table 7). The evaluation results regarding BS-15 showed that the crop model simulated above-ground biomass in the second and third sowings with estimated error differences of $11.85 \%$ and $9.93 \%$. The calculated d-index value was 0.83 , the mean percent difference (MPD) value was $9.84 \%$, and the root means square error (RMSE) value was $963.11 \mathrm{~kg} \mathrm{ha}^{-1}$. The $\mathrm{d}$-index value designates a significant relationship between the experiential and simulated values of this factor (Table 7).

\subsection{Model Validation with Surveyed Data}

The surveyed data, including the crop husbandry practices of farmers in the project areas (Bahawalpur and Khanewal), were used as the input data set, and the model was validated to assess its accuracy in the farmer's field (Figure 7). The results showed that the model accounts for the effect of crop husbandry, e.g., the differences in fertilizers, irrigation variety, and weather data for each location. The data presented in Table 8 shows that the model simulated the SCY of different cultivars well, with an average mean percent difference of $-0.65 \%$ and a RMSE of $27.88 \mathrm{~kg} \mathrm{ha}^{-1}$ for the Bahawalpur area (Table 8). Similar results were observed for the Khanewal district area (Table 9), where the MPD ranges from $-4.74 \%$ to $26.52 \%$ with an average of $4.91 \%$ during the year 2018 and a RMSE of $42.06 \mathrm{~kg} \mathrm{ha}^{-1}$. The model simulation was further assessed with the farmer data set collected during 2019. Significant results were recorded with high values of $R^{2}$ and $D$ index and low values of error and RMSE for both the Bahawalpur and Khanewal districts (Figures 8 and 9) for the year 2019.

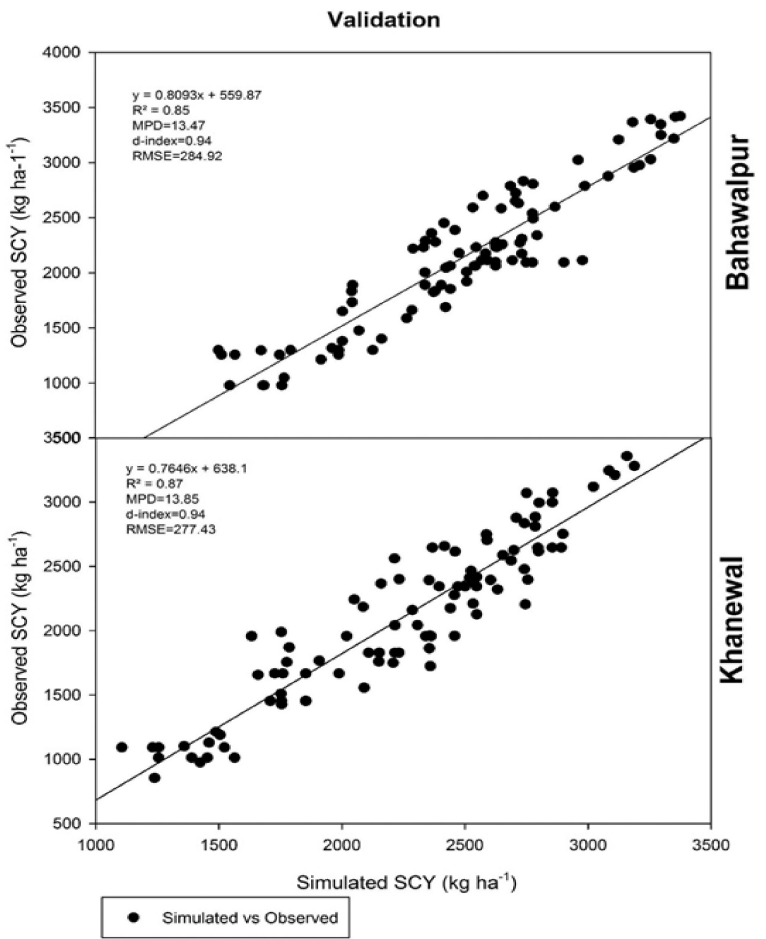

Figure 7. Relationship between the simulated and observed SCY during the validation of the model with data recorded during a survey at a farmer's field in the project area during 2019. 
Table 8. Comparison of the observed and simulated results of the model validation with data recorded for different cotton cultivars sown on 2 May 2018 at a farmer's field in the Bahawalpur district.

\begin{tabular}{ccccc}
\hline Cultivars & $\begin{array}{c}\text { Obs. } \\
\text { SCY } \\
\mathbf{( k g ~ h a ~}^{-\mathbf{1}} \mathbf{)}\end{array}$ & $\begin{array}{c}\text { Sim. } \\
\mathbf{S C Y} \\
\mathbf{( k g ~ h a -}^{-\mathbf{1}} \mathbf{)}\end{array}$ & $\begin{array}{c}\text { RMSE } \\
\mathbf{k g ~ h a}^{-\mathbf{1}} \mathbf{)}\end{array}$ & $\begin{array}{c}\text { MPD } \\
\mathbf{( \% )}\end{array}$ \\
\hline BS-15 & 3347.01 & 3257.43 & 20.03 & -2.68 \\
IUB-13 & 2789.70 & 2886.82 & 21.72 & 3.48 \\
Mubarak & 1382.59 & 1454.59 & 72.00 & 5.21 \\
GH-Uhad & 2584.22 & 2479.72 & 23.37 & -4.04 \\
Debal & 2180.25 & 2274.55 & 21.09 & 4.33 \\
Cyto-179 & 3251.20 & 3258.54 & 1.64 & 0.23 \\
NIAB-Kiran & 2652.30 & 2549.20 & 23.05 & -3.89 \\
CIM-313 & 2289.26 & 2109.67 & 40.16 & -7.84 \\
Average & 2559.57 & 2565.07 & 27.88 & -0.65 \\
\hline
\end{tabular}

Note: Obs = observed; Sim = simulated; SCY = seed cotton yield; MPD = mean percent difference; RMSE = root mean square error.

Table 9. Comparison of the observed and simulated results of the model validation with data recorded for different cotton cultivars sown on 2 May 2018 at a farmer's field in the Khanewal district.

\begin{tabular}{ccccc}
\hline Cultivars & $\begin{array}{c}\text { Obs. } \\
\text { SCY } \\
\mathbf{( k g ~ h a}^{-1} \mathbf{)}\end{array}$ & $\begin{array}{c}\text { Sim. } \\
\mathbf{S C Y} \\
\mathbf{( k g ~ h a}^{-\mathbf{1}} \mathbf{)}\end{array}$ & $\begin{array}{c}\text { RMSE } \\
\mathbf{( k g ~ h a}^{-\mathbf{1}} \mathbf{)}\end{array}$ & $\begin{array}{c}\text { MPD } \\
\mathbf{( \% )}\end{array}$ \\
\hline BS-15 & 2996.48 & 2854.55 & 31.74 & -4.74 \\
IUB-13 & 2210.46 & 2532.78 & 72.07 & 14.58 \\
Mubarak & 1189.19 & 1504.59 & 70.53 & 26.52 \\
GH-Uhad & 2834.28 & 2741.59 & 20.73 & -3.27 \\
Debal & 2625.00 & 2698.55 & 16.45 & 2.80 \\
Cyto-179 & 3209.94 & 3108.54 & 22.67 & 12.98 \\
NIAB-Kiran & 2042.40 & 2307.41 & 59.26 & -6.42 \\
CIM-313 & 2993.76 & 2801.47 & 43.00 & 4.91 \\
Average & 2512.69 & 2568.69 & 42.06 & \\
\hline
\end{tabular}

Note: Obs = observed; Sim = simulated; SCY = seed cotton yield; MPD = mean percent difference; RMSE = root mean square error.

\section{Bahawalpur}

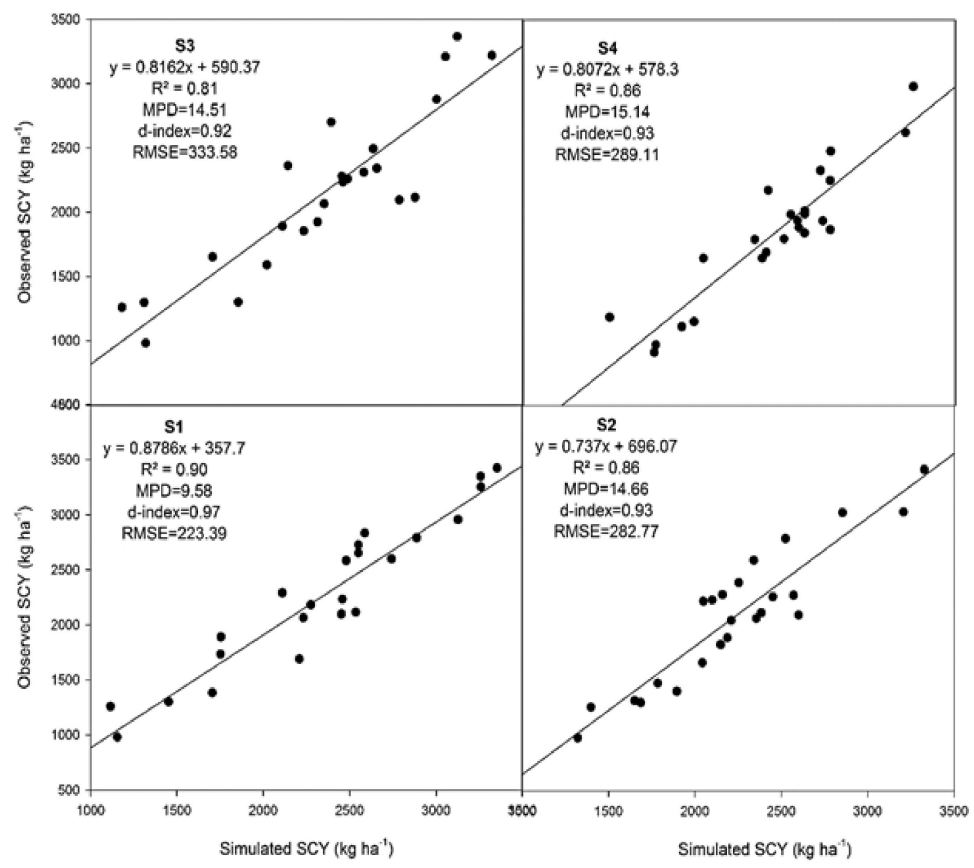

Figure 8. Relationship between the simulated and observed SCY during the validation of the model with data recorded during a survey at a farmer's field in the Bahawalpur district during 2019. 


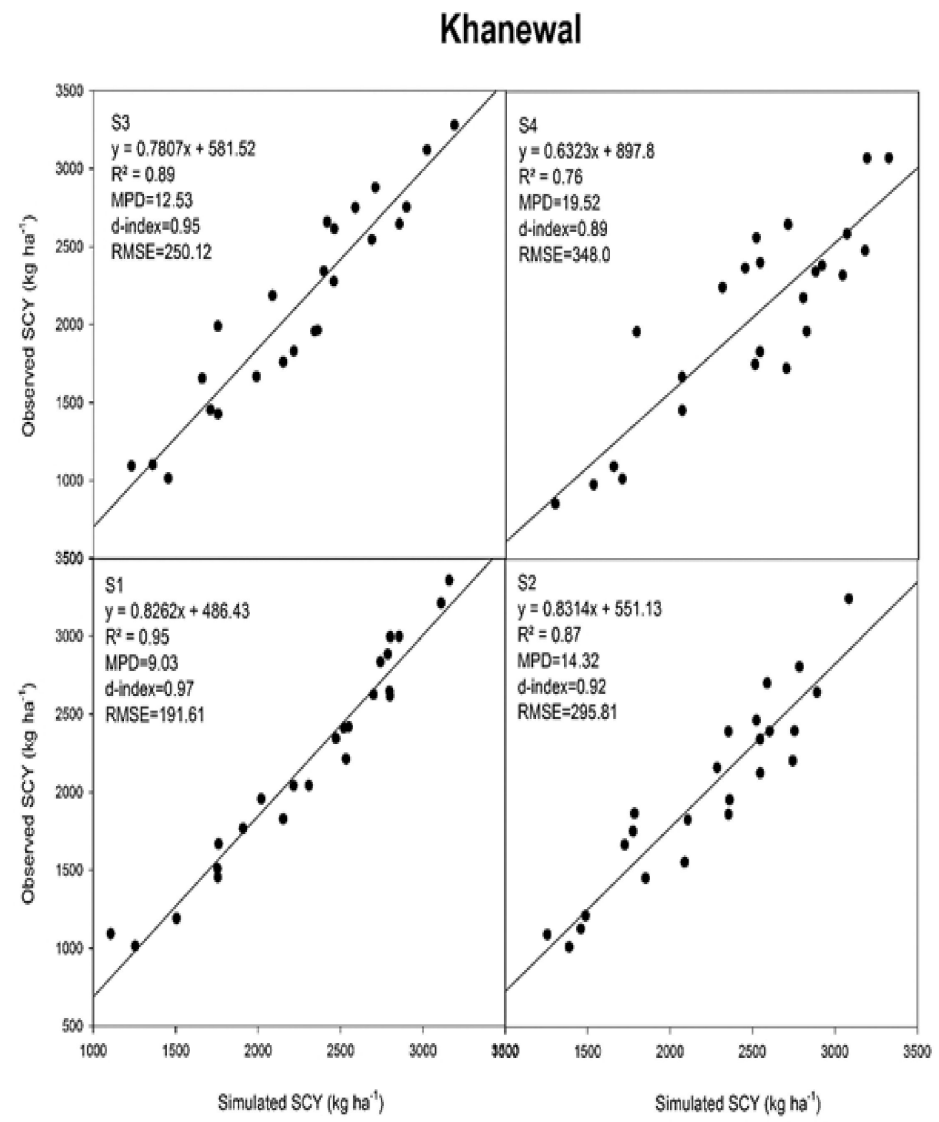

Figure 9. Relationship between the simulated and observed SCY during the validation of the model with data recorded during a survey at a farmer's field in the Khanewal district during 2019.

The highest changes of the probable hot/wet climate conditions in the future may be attributed to a significant increase in maximum temperature in the May, June, and July (MJJ) months of the cotton season, with an average projected increase of $3.9^{\circ} \mathrm{C}$ over the season. The highest of the changes under hot/wet conditions may be attributed to the average increase of $4.5^{\circ} \mathrm{C}$ in the MJJ months of the cotton-growing season under the RCP 8.5 scenario. The output of the GCM Geophysical Fluid Dynamics Laboratory Climate Model (GFDL-CM3) was selected for the study. This model predicted the highest change in Tmax and Tmin for the project area, as clear from Figures 10 and 11.

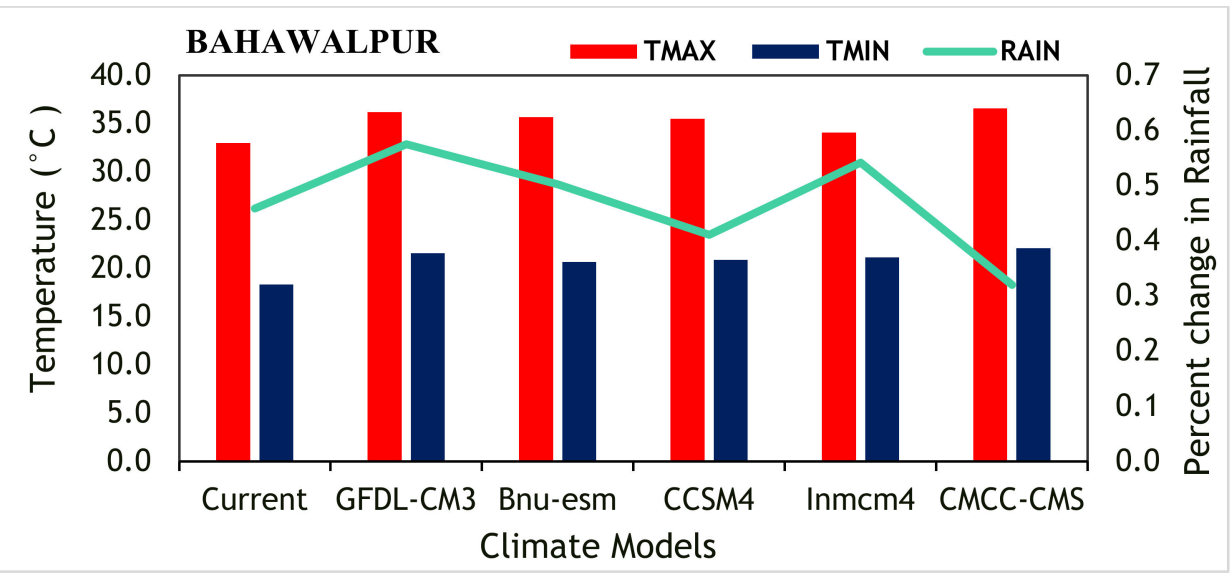

Figure 10. Climate Change Projection under RCP 8.5 for the Bahawalpur area. 


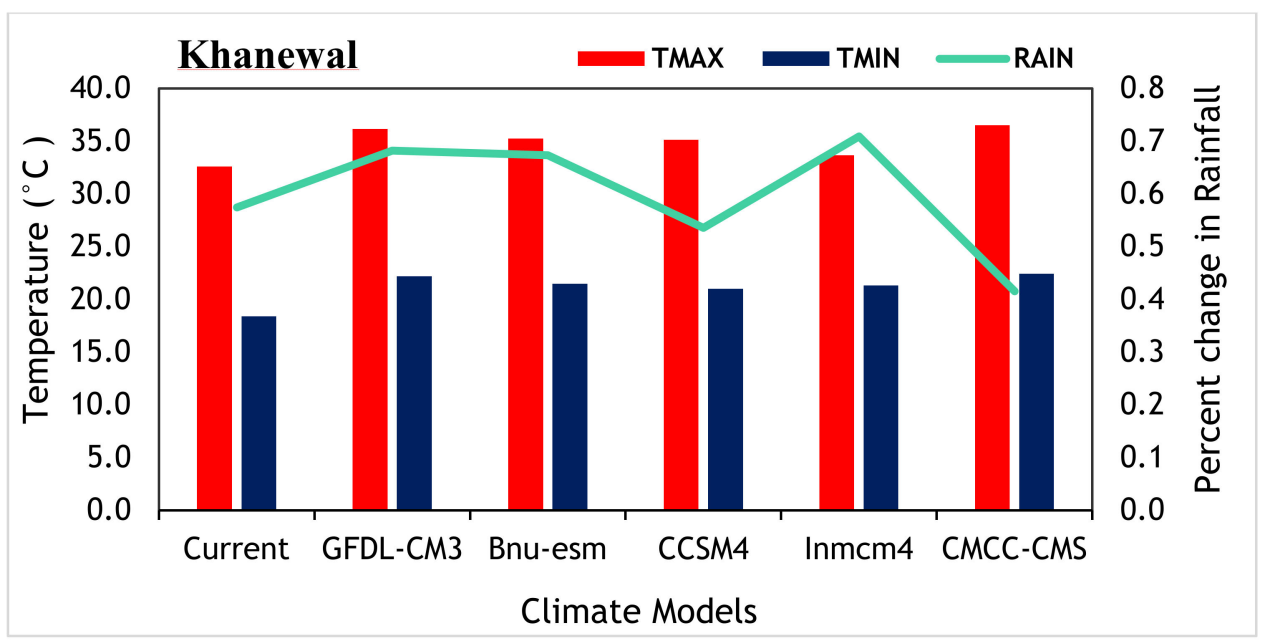

Figure 11. Climate Change Projection under RCP 8.5 for Khanewal area.

The results of the calibration and evaluation with an experimental data set and further validation of the model at the farmer's field showed that the CS

M-CROPGRO-Cotton in the shell of DSSAT can be used for assessing the impact of climate change on cotton productivity and the optimization of crop production options for current and future climatic conditions.

\subsection{Impact of Mid Century (2040-2069) Climate Change Scenarios}

The current crop area and production in the project are presented in Table 10. The crop husbandry parameter used in the X-build file is given in Table 11. The comparison of baseline and future simulations showed that climate change would reduce cotton yield (Figure 12). After the calibration and validation of experimental and survey data, the model was run with thirty years of historical climate (1989-2019) data for simulations for the development of baseline and generated data GCM (GFDL-CM3) for the years 2040-2069 under RCP 4.5 and 8.5 for future climate change scenarios (Tables 12 and 13).

Table 10. Comparison of area, production, and average $\mathrm{SCY}$ in the project area.

\begin{tabular}{|c|c|c|c|c|c|c|c|}
\hline \multirow[b]{2}{*}{ District } & \multicolumn{3}{|c|}{2018} & \multicolumn{3}{|c|}{2019} & \multirow{2}{*}{$\begin{array}{c}\text { Average } \\
\text { Yield } \\
\left(\mathrm{kg} \mathrm{ha}^{-1}\right)\end{array}$} \\
\hline & $\begin{array}{c}\text { Area } \\
(000 \text { ha })\end{array}$ & $\begin{array}{l}\text { Production } \\
\text { Bales * }\end{array}$ & $\begin{array}{c}\text { Yield } \\
\left(\mathrm{kg} \mathrm{ha}^{-1}\right)\end{array}$ & $\begin{array}{c}\text { Area } \\
(000 \text { ha })\end{array}$ & $\begin{array}{l}\text { Production } \\
\text { Bales }\end{array}$ & $\begin{array}{c}\text { Yield } \\
\left(\mathrm{kg} \mathrm{ha}^{-1}\right)\end{array}$ & \\
\hline Bahawalpur & 268.5 & 1125.0 & 2018 & 265.5 & 992.0 & 1794 & 1906 \\
\hline Khanewal & 179.7 & 769.4 & 2056 & 167.1 & 682.9 & 1788 & 1922 \\
\hline
\end{tabular}

Table 11. Crop husbandry practices used in the area for cotton production at farmer's fields.

\begin{tabular}{ccccccc}
\hline District & Variety & Sowing Time & $\begin{array}{c}\text { Nitrogen } \\
\text { kg acre }^{-\mathbf{1}}\end{array}$ & $\begin{array}{c}\text { Phosphorus } \\
\text { kg acre }^{-\mathbf{1}}\end{array}$ & $\begin{array}{c}\text { No of Sprays } \\
\text { Irrigations }\end{array}$ \\
\hline Bahawalpur & IUB-13 & 15 May & 67 & 20.4 & 5 & 16 \\
Khanewal & IUB-13 & 15 May & 56 & 22.5 & 7 & 15 \\
\hline
\end{tabular}




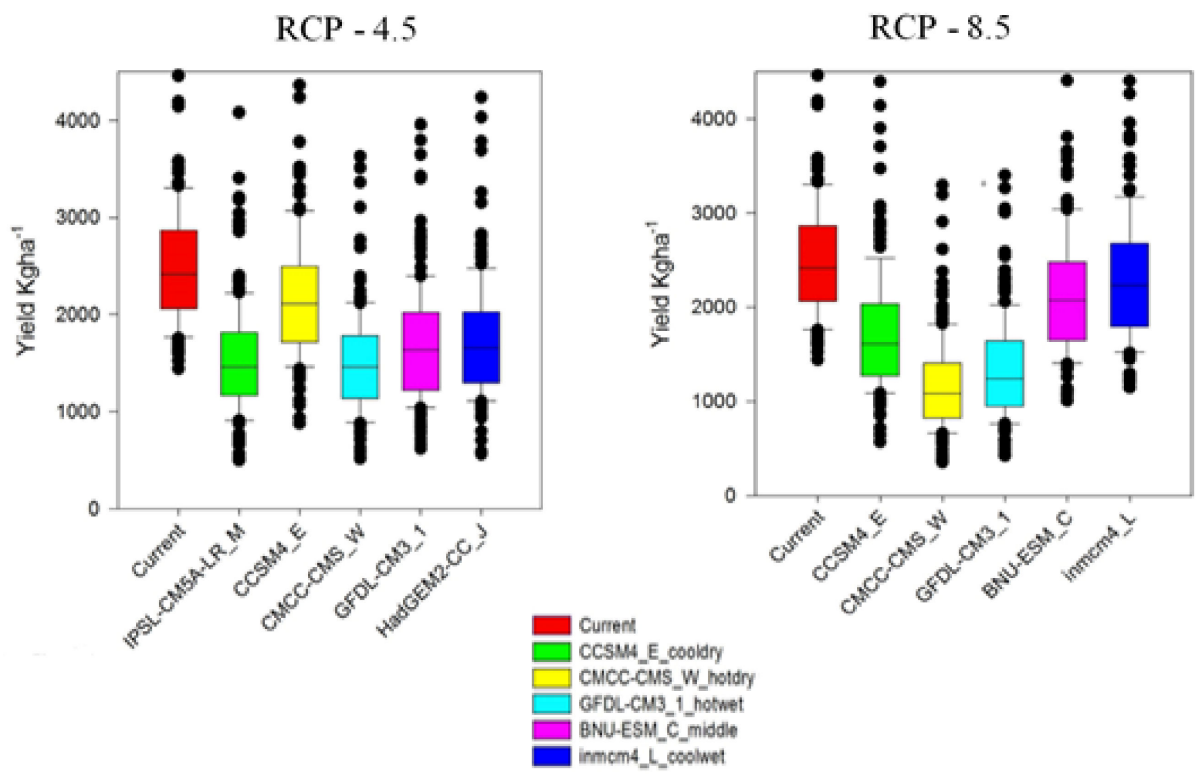

Figure 12. Impact of climate change predicted by different GCMs for 2040-2069 under RCPs 4.5 and 8.5 for the Project Area.

Table 12. Impact of climate change predicted for 2040-2069 under the representative concentration pathway (RCP 4.5) on cotton yield in the project area.

\begin{tabular}{|c|c|c|c|c|c|}
\hline \multirow[b]{2}{*}{ District } & \multicolumn{3}{|c|}{ Average Cotton Yield (kg ha-1) } & \multicolumn{2}{|c|}{ Yield Difference } \\
\hline & $\begin{array}{c}\text { Baseline } \\
\text { (1989-2019) }\end{array}$ & $2018 \& 2019$ & $\begin{array}{l}\text { GFDL-CM3 } \\
\text { (2040-2069) }\end{array}$ & $\left(\mathrm{kg} \mathrm{ha}^{-1}\right)$ & $\%$ \\
\hline Bahawalpur & 2356 & 1906 & 1653 & -703 & -29.84 \\
\hline Khanewal & 2505 & 1922 & 1965 & -540 & -21.56 \\
\hline Average & 2356 & 1906 & 1653 & -621.5 & -25.7 \\
\hline
\end{tabular}

Table 13. Impact of climate change predicted for 2040-2069 under the representative concentration pathway (RCP 8.5) on cotton yield in the project area.

\begin{tabular}{cccccc}
\hline \multirow{2}{*}{ District } & \multicolumn{2}{c}{ Average Cotton Yield (kg ha $\mathbf{~}^{\mathbf{1}} \mathbf{)}$} & \multicolumn{2}{c}{ Yield Difference } \\
\cline { 2 - 6 } & $\begin{array}{c}\text { Baseline } \\
\mathbf{( 1 9 8 9 - 2 0 1 9 )}\end{array}$ & $\mathbf{2 0 1 8} \& \mathbf{2 0 1 9}$ & $\begin{array}{c}\text { GFDL-CM3 } \\
\mathbf{( 2 0 4 0 - 2 0 6 9 )}\end{array}$ & $\mathbf{( k g ~ h a}^{-\mathbf{1})}$ & \% \\
\hline Bahawalpur & 1906 & 2356 & 1565 & -791 & -33.57 \\
Khanewal & 1922 & 2505 & 1735 & -770 & -30.74 \\
\hline Average & 1914 & 2431 & 1650 & -781 & -32.16 \\
\hline
\end{tabular}

\subsection{Selection of Suitable Variety}

A comparison of cotton verities showed that Mubarak and Debal perform better than other varieties at the Khanewal location, while Mubarak and CIM-313 perform better than others at Bahawalpur. However, Mubarak performs better at both location and produce SCY $2907 \mathrm{~kg} \mathrm{ha}^{-1}$. The poorest performance $\left(1244 \mathrm{~kg} \mathrm{ha}^{-1}\right)$ was observed in Cyto-179 (Figure 13). 


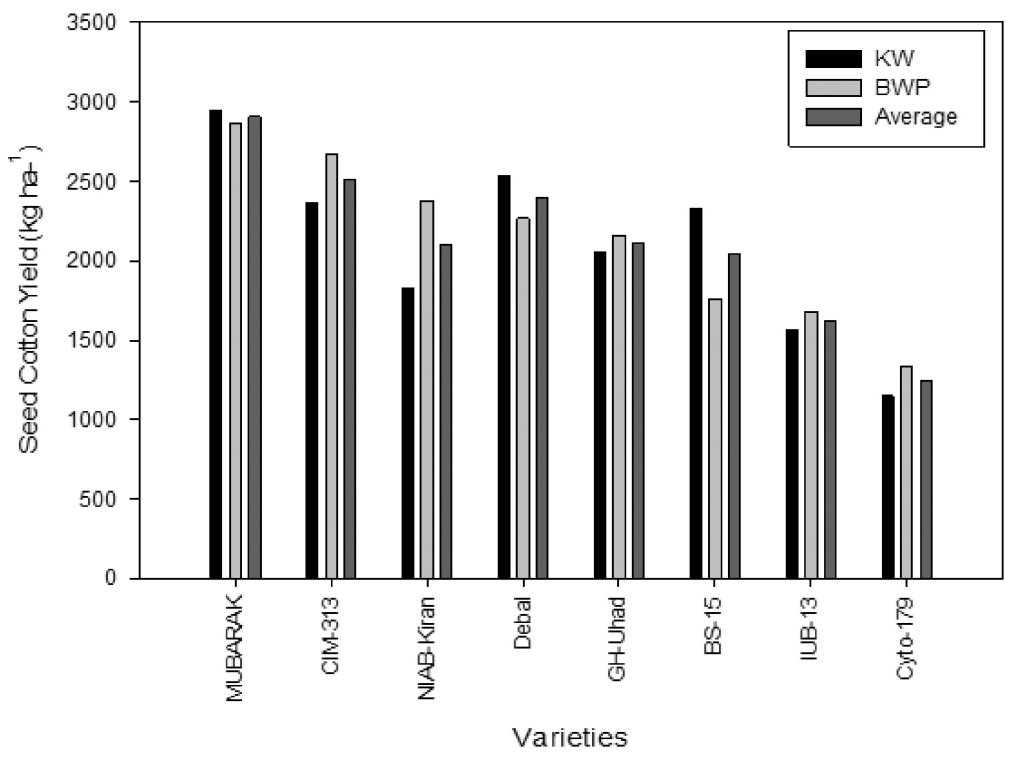

Figure 13. Comparison of different cotton cultivars at the Bahawalpur and Khanewal locations.

\subsection{Optimization of Planting Time}

The same behavior was shown by different varieties against planting dates. So the better performing variety Mubarak was used in further simulations for the development of the adaptation package. The model was run with seven planting dates $(-45,-30,-15,0$, $+15,+30$, and +45 ) with an interval of 15 days. The current sowing date was 15 May (0). The model was run with 30 years of climatic data (2040-2069) generated by GCM (GFDL-CM3) for mid-century scenarios under RCP 4.5 and 8.5. The results showed that planting 15 and 30 days earlier would be the best strategy for both locations under RCP 4.5 and 8.5 (Figures 14 and 15).

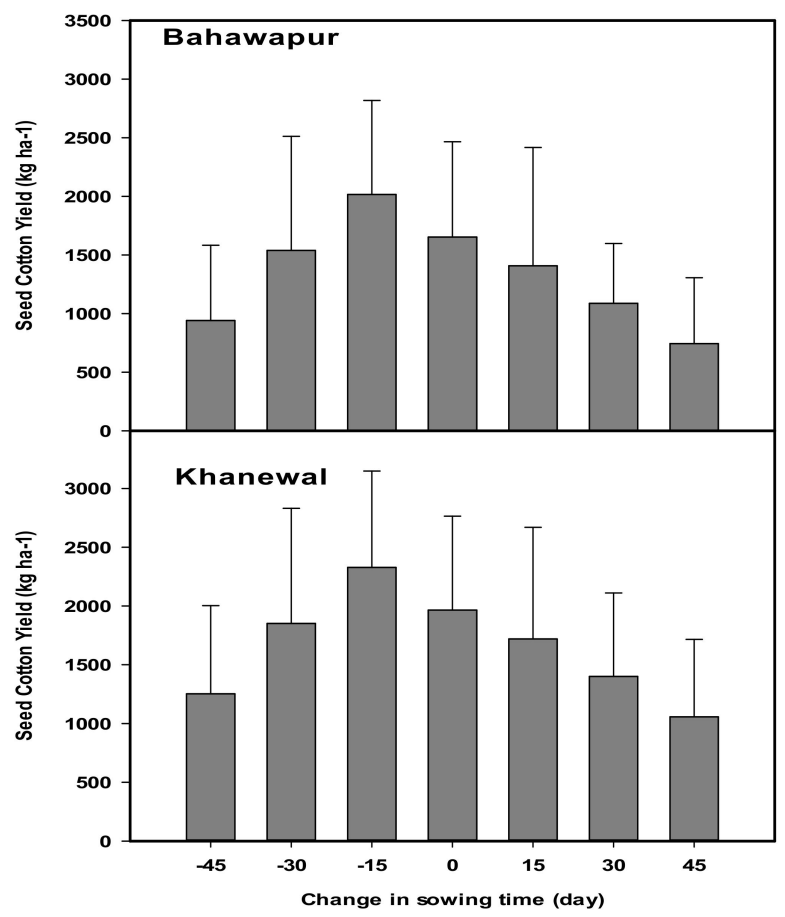

Figure 14. Optimization of the planting date for maximizing cotton production $\left(\mathrm{kg} \mathrm{ha}^{-1}\right)$ under the changing climate scenario (2040-2069) of RCP 4.5. Current planting date: 15 May (0). 


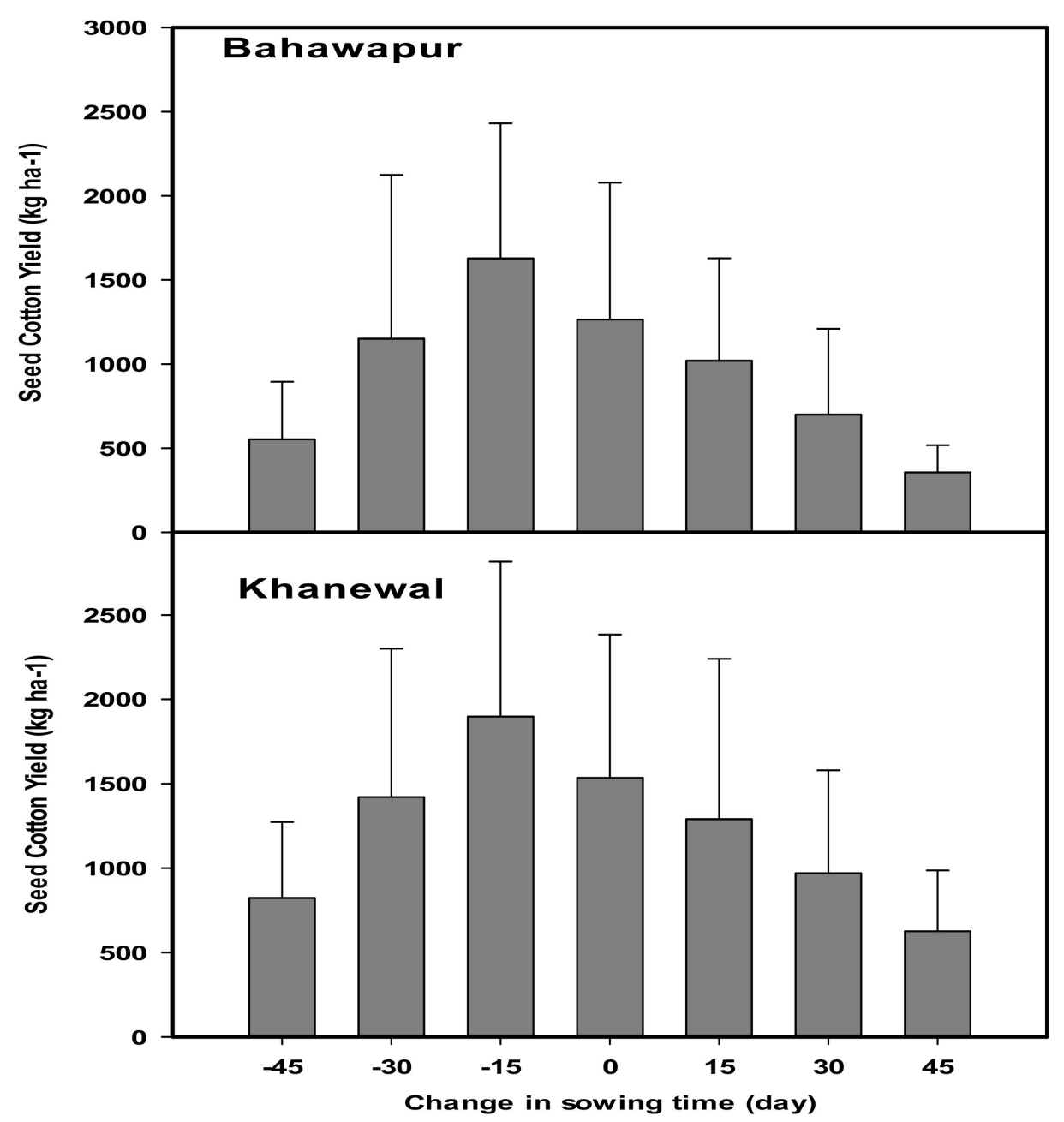

Figure 15. Optimization of the planting date for maximizing cotton production $\left(\mathrm{kg} \mathrm{ha}^{-1}\right)$ under the changing climate scenario (2040-2069) of RCP 8.5. Current planting date: 15 May (0).

\subsection{Optimization of Planting Density}

The model was run with three planting densities $(46,500,62,000$, and 93,000 plants per hectare) developed by varying plant-to-plant distances $(15,22.5$, and $30 \mathrm{~cm})$ in the field. The results showed that under future climate scenarios, 62000 plants per hectare will maximize the SCY during 2040-2069 under both RCP 4.5 and 8.5 in the project area (Figure 16). A further increase in plant population per unit area will increase the plant-to-plant competition for nutrition, space, light, air, etc. and decrease the yield. 

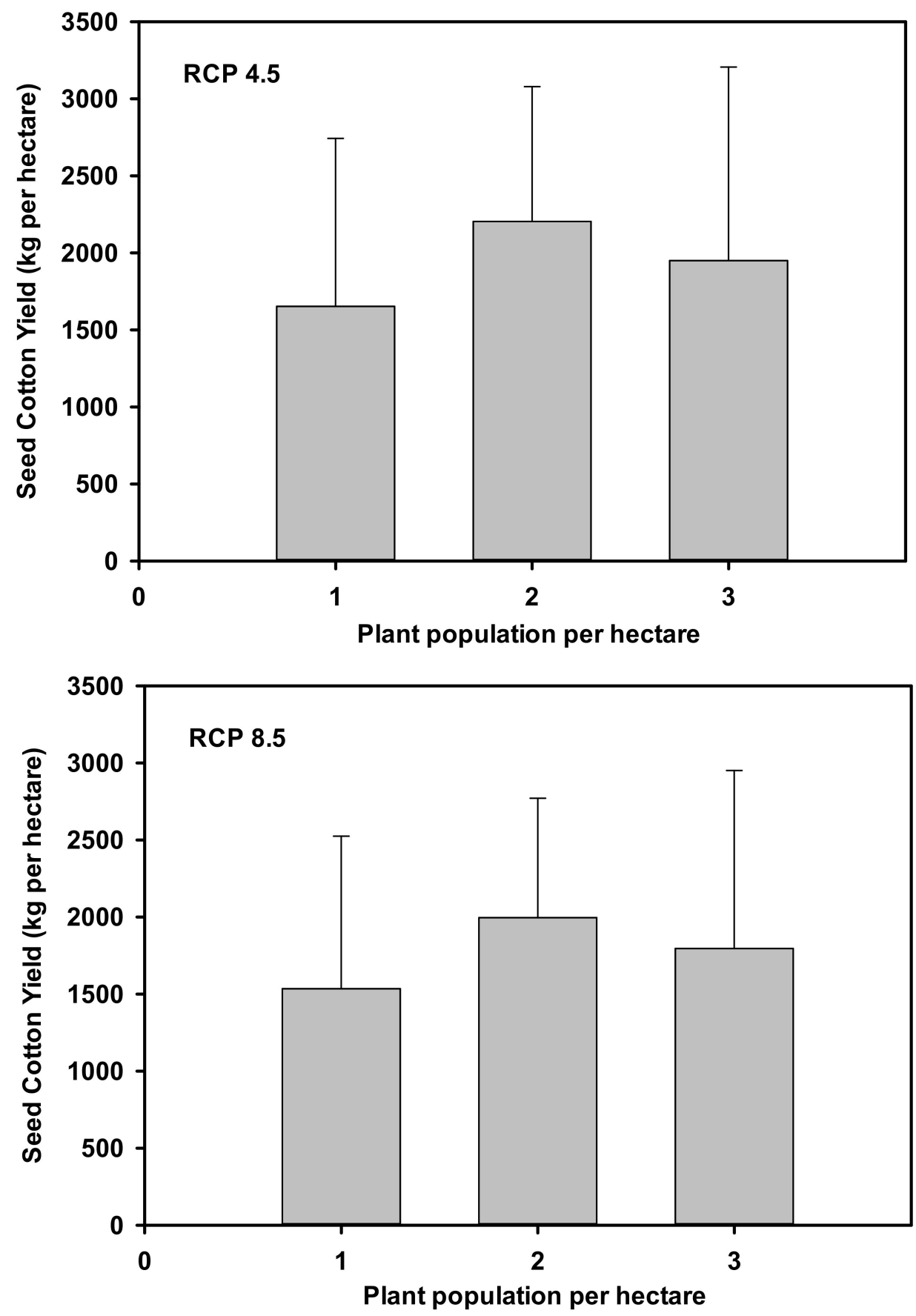

Figure 16. Optimization of planting density (1:46,500, 2:62,000 and 3:93,000 plants) for maximizing cotton production $\left(\mathrm{kg} \mathrm{ha}^{-1}\right)$ under the changing climate scenario (2040-2069) of RCP 4.5 and 8.5.

\subsection{Optimization of Amount of Nitrogen}

Nitrogen $(\mathrm{N})$ is an essential nutrient for better crop growth, and our soils are deficient in organic matter and nitrogen. During the early crop season, the cotton zone faces high temperatures and less rainfall. These arid environmental conditions reduce the organic matter and nitrogen in these soils. Keeping in view the importance of nitrogen, the model was run with ten nitrogen levels $\left(25,50,75,100,125,150,175,200,225\right.$, and $\left.250 \mathrm{~kg} \mathrm{ha}^{-1}\right)$ to discover the optimum rate for better cotton production. The results showed that nitrogen application had a linear relationship with SCY until $150 \mathrm{~kg} \mathrm{~N} \mathrm{ha}^{-1}$. After that addition, the crop yield is not effected (Figure 17). It can be concluded that $150 \mathrm{~kg} \mathrm{~N} \mathrm{ha}^{-1}$ will be the best strategy for maximizing crop yield under future scenarios at both locations. 


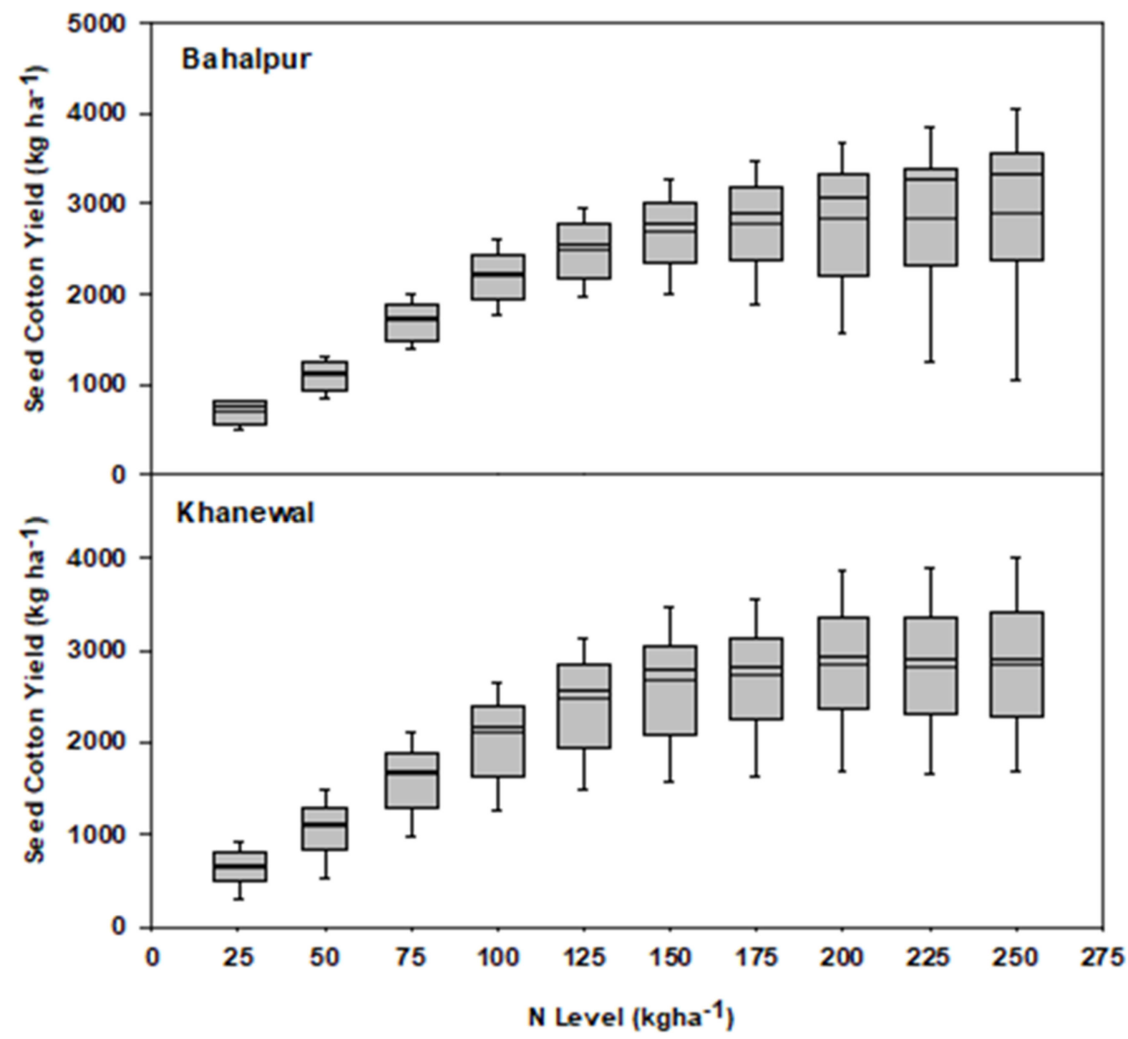

Figure 17. Impact of the nitrogen level on SCY $\left(\mathrm{kg} \mathrm{ha}^{-1}\right)$ at the Bahawalpur and Khanewal districts.

\subsection{Adaptation Package for Climate-Resilient Cotton Production}

Agricultural production systems are complex, interlinked, and dependent on various factors. Crop production is the climate-prone sector of the economy. The anticipation of and adaptations to climate change are important. There are certain planned and unplanned adaptations regarding climate vulnerability in agricultural systems that maintain the balance in the ecosystem and minimize economic losses. The policies regarding high development must have a synergy effect with climate change for the better adaptive capacity of the nation. To minimize the climate losses, there can be adaptation strategies on farm/regional and national levels. After doing the above sensitivity analysis against different production options, a biophysically viable adaptation package was developed for the climate-resilient cotton production in the area (Table 14). To make the adaptation package more reliable, the model was run with 30 years of climatic data (2040-2069). The results showed that with the adoption of this package, there will be $11 \%$ benefits over baseline and $33 \%$ recovery of climate change damages under RCP 4.5 projections (Table 15). The model was run with 30 years of future climate data for 2040-2069 under RCP 8.5 for the evaluation adaptation package. The results showed that the package will help the farmers increase crop yield $7.5 \%$ over baseline yield and help recover $37 \%$ of the damages due to climate change RCP 8.5 projections (Table 16).

Table 14. Adaptation Package climate-resilient cotton production in the project area.

\begin{tabular}{ccc}
\hline Variables & Direction of Change & Percentage Change \\
\hline Nitrogen $\left(\mathrm{kg} \mathrm{ha}^{-1}\right)$ & Increase & 10 \\
Planting density $\left({\left.\text { Plant } \mathrm{m}^{-2}\right)}_{\text {Irrigation Management }}^{\text {Sowing Dates }}\right.$ & Increase & 5 \\
Secrease & 10 \\
Fertilizer application method & Early & 15 days \\
Variety selection & \multicolumn{2}{c}{ Fertigation } \\
\end{tabular}


Table 15. Impact of the adaptation package on SCY under the present and future climate scenarios of the representative concentration pathway (RCP 4.5).

\begin{tabular}{|c|c|c|c|c|c|c|c|}
\hline \multirow[t]{2}{*}{ District } & \multirow{2}{*}{$\begin{array}{l}\text { Baseline } \\
\text { 1989-2019 }\end{array}$} & \multirow{2}{*}{$\begin{array}{c}\text { GFDL-CM3 } \\
2040-2069\end{array}$} & \multirow{2}{*}{$\begin{array}{c}\begin{array}{c}\text { With } \\
\text { Adaptation }\end{array} \\
2040-2069\end{array}$} & \multicolumn{2}{|c|}{ Recovery over Baseline } & \multicolumn{2}{|c|}{$\begin{array}{c}\text { Recovery over Future } \\
\text { Climate }\end{array}$} \\
\hline & & & & $\left(\mathrm{kg} \mathrm{ha}^{-1}\right)$ & $\%$ & $\left(\mathrm{~kg} \mathrm{ha}^{-1}\right)$ & $\%$ \\
\hline Bahawalpur & 2356 & 1653 & 2592 & 235.6 & 10.0 & 938.6 & 36.2 \\
\hline Khanewal & 2505 & 1965 & 2806 & 300.6 & 12.0 & 840.6 & 29.9 \\
\hline Average & 2431 & 1809 & 2699 & 268.1 & 11.0 & 889.6 & 33.1 \\
\hline
\end{tabular}

Table 16. Impact of the adaptation package on SCY under the present and future climate scenarios of the representative concentration pathway (RCP 8.5).

\begin{tabular}{|c|c|c|c|c|c|c|c|}
\hline \multirow[t]{2}{*}{ District } & \multirow{2}{*}{$\begin{array}{l}\text { Baseline } \\
\text { 1989-2019 }\end{array}$} & \multirow{2}{*}{$\begin{array}{c}\text { GFDL-CM3 } \\
2040-2069\end{array}$} & \multirow{2}{*}{$\begin{array}{c}\begin{array}{c}\text { With } \\
\text { Adaptation }\end{array} \\
2040-2069\end{array}$} & \multicolumn{2}{|c|}{ Recovery over Baseline } & \multicolumn{2}{|c|}{$\begin{array}{c}\text { Recovery over Future } \\
\text { Climate }\end{array}$} \\
\hline & & & & $\left(\mathrm{kg} \mathrm{ha}^{-1}\right)$ & $\%$ & $\left(\mathrm{~kg} \mathrm{ha}^{-1}\right)$ & $\%$ \\
\hline Bahawalpur & 2356 & 1565 & 2545 & 188.0 & 8.0 & 979.5 & 38.5 \\
\hline Khanewal & 2505 & 1735 & 2680 & 175.0 & 7.0 & 945.4 & 35.3 \\
\hline Average & 2431 & 1650 & 2613 & 181.5 & 7.5 & 962.5 & 36.9 \\
\hline
\end{tabular}

\section{Discussion}

CROPGRO-Cotton in the shell of DSSAT has been tested by researchers for the growth and yield simulation of crops sown under different climatic conditions with different crop management practices $[13,25,33-35]$. These studies concluded that CROPGRO-Cotton is capable of estimating climatic impacts on cotton crops. The estimation of climatic impact and possible adaptations for Pakistani cotton with the model are vitally important. The CSM-CROPGRO-Cotton model was well parameterized using the data of field trials conducted at the University of Agriculture, Faisalabad and the surveyed data of farmers fields at the Bahawalpur and Khanewal districts of Punjab-Pakistan. The Model performed well during the calibration for all studied parameters presented in Table 5. The lowest percent error showed a low variation between the observed and predicted values, which indicates the accuracy of the model during calibration. The slight over-prediction in days to flowering, TDM accumulation, and SCY and the under-prediction in days to physiological maturity and LAI might be due to the poor prediction of seedling emergence at lower soil temperature. The model computed soil temperature from the air temperature for the upper soil layer, while in deeper layers it was computed from the annual air temperature [10]. The model simulated fairly well the dynamics in SCY and TDM for most of the planting dates. Similar performance of the model was also reported by Wajid et al. [36] for SCY with lower MPD values of $5.30 \%$ and $4.38 \%$ during the calibration and evaluation, respectively, while he was studying the impact of the planting date on cotton performance. Furthermore, an analysis of seasonal simulations exposed that late planting had increased the risk of obtaining very low SCY. This risk was generated by climatic conditions such as lesser solar radiation and variations in temperature, precipitation, and photothermal units when planting was too late and too early (Tables 8 and 9).

The model validation with surveyed data including the crop husbandry practices of farmers in Bahawalpur and Khanewal showed that the model accounts for the effect of crop husbandry, e.g., differences in fertilizers, irrigation variety, and weather data for each location (Figure 6). The comparison of values showed that the model simulated the SCY of different cultivars well, with an average mean percent difference of $-0.65 \%$, and $4.9 \%$ at Bahawalpur and Khanewal (Tables 8 and 9). The model simulation was further assessed with the farmer data set collected during 2019. Significant results were recorded with high values of R2 and D-index and low values of error and RMSE for both the Bahawalpur and Khanewal districts (Figures 7 and 8) for the year 2019. These results of calibration and evaluation with an experimental data set and the further validation of the 
model at farmers' fields showed that the CSM-CROPGRO-Cotton in the shell of DSSAT can be used for assessing the impact of climate change on cotton productivity and for the optimization of crop production options for current and future climatic conditions. Overall, a comparison of the simulated and observed data showed that the model simulated well under the non-limiting condition as compared to under stressed conditions.

To make the adaptation package more reliable, the model was run with 30 years of climatic data (2040-2069). Future climate data for 2040-2069 under RCP 4.5 and 8.5 will be damaging for cotton production due to high temperature and lesser rainfall, as predicted under RCP 4.5 and 4.8 (Tables 12 and 13), which will be a cause of lesser production under the arid environments of Bahawalpur and Khanewal with present crop husbandry practices. However, the results showed that RCP 8.5 will be more damaging than such types, results that were also reported by San José et al. and Abadie et al. [37,38].

The model was run with different production options for developing the adaptations to minimize the adverse effects of the changing climate. The results showed that with the adoption of this package, there will be $11 \%$ benefits over baseline and $33 \%$ recovery of climate change damages under RCP 4.5 (Table 15). The results displayed that the package will help the farmers increase crop yield $7.5 \%$ over baseline yield and help recover $37 \%$ of the damages due to climate change, under RCP 8.5 projections (Table 16). An early sowing date (15 days earlier than present) will be the best strategy along with other proposed options for the future, as late planting pushes the crop into a lower radiation time of the year. The higher temperatures at early vegetative growth phases led to earlier flowering, boll set, boll opening and the lower growth of canopy (LAI) these results are in line with Wajid et al. [36], who applied CSM-CROPGRO-Cotton for the optimization of different cotton management practices under the semi-arid climatic conditions in central Punjab.

These benefits of the adaptation package will be more if plant breeders help to evolve more heat and drought - tolerant varieties than the present-day varieties such as Mubarak. The breed is suggesting an emphasis on fast-growing varieties with lesser LAI and no stomata on leaves to avoid excessive transpiration losses.

\section{Conclusions}

The current study revealed that that the CSM-CROPGRO-Cotton model in the shell of DSSAT V. 4.7 is an artistic tool for the simulation of crop growth, phenology, and yield. A close agreement between the simulated and observed data is proof of these qualities. Furthermore, a well-calibrated CSMCROPGRO-Cotton and validated model could be used for climate change impact assessment and the optimization of site-specific production technology with the use of minimum resources. The proposed adaptation package could be proven effective in quantifying the climate change impact on SCY in the project area and in developing possible adaptation strategies for sustainable cotton production that can mitigate the harsh effects of climate change.

Author Contributions: All authors have participated in (a) the conception and design or analysis and interpretation of the data; (b) drafting the article or revising it critically for important intellectual content, and (c) the approval of the final version. Conceptualization, A.I. and M.M.A.; methodology, T.K. and Z.A.A.; validation, T.K.; formal analysis, A.A.; investigation, M.I., M.J.A. and Z.A.A.; data curation, T.K.; visualization, A.A.; writing-original draft preparation, T.K.; writing-review and editing, Z.A.A.; supervision, M.M.A.; project administration, A.I. All authors have read and agreed to the published version of the manuscript.

Funding: This research was funded by WWF-Sweden, grant number "30026" and "The APC was funded by 30026".

Institutional Review Board Statement: No applicable.

Informed Consent Statement: No applicable.

Data Availability Statement: No applicable. 
Acknowledgments: The authors highly acknowledge the services of the Department of Agronomy, University of Agriculture Faisalabad (UAF), Pakistan for providing the platform to carry out the present research work.

Conflicts of Interest: The authors declare that they have no conflict of interest.

\section{References}

1. Arshad, A.; Raza, M.A.; Zhang, Y.; Zhang, L.; Wang, X.; Ahmed, M.; Habib-ur-Rehman, M. Impact of Climate Warming on Cotton Growth and Yields in China and Pakistan: A Regional Perspective. Agriculture 2021, 11, 97. [CrossRef]

2. Ullah, A.; Ahmad, A.; Khaliq, T.; Akhtar, J. Recognizing production options for pearl millet in Pakistan under changing climate scenarios. J. Integr. Agric. 2017, 16, 762-773. [CrossRef]

3. Zhu, T.; Ringler, C.; Iqbal, M.M.; Sulser, T.B.; Goheer, M.A. Climate change impacts and adaptation options for water and food in Pakistan: Scenario analysis using an integrated global water and food projections model. Water Int. 2013, 38, 651-669. [CrossRef]

4. Iqbal, M.; Ul-Allah, S.; Naeem, M.; Ijaz, M.; Sattar, A.; Sher, A. Response of cotton genotypes to water and heat stress: From field to genes. Euphytica 2017, 213, 131. [CrossRef]

5. International Trade Centre. Cotton and Climate Change: Impacts and Options to Mitigate and Adapt; Technical Paper, Doc. No. MAR-11-200; EITC: Geneva, Switzerland, 2011; Volume xii, 32p.

6. Naheed, G.; Rasul, G. Recent Water Requirement of Cotton Crop in Pakistan. Pak. J. Meteor. 2010, 6, 75-84.

7. Ahmad, A.; Ashfaq, M.; Rasul, G.; Wajid, S.A.; Ahmad, I.; Khaliq, T.; Nasir, J.; Rasul, F.; Riaz, F.; Ahmad, B.; et al. Development of Climate Change Adaptation Strategies for Cotton-Wheat Cropping System of Punjab Pakistan in Handbook of Climate Change and Agroecosystems; Rosenzweig, C., Mutter, C.Z., Contreras, E.M., Eds.; World Scientific: Singapore, 2021. [CrossRef]

8. Rahman, M.H.; Ahmad, A.; Wajid, A.; Hussain, M.; Rasul, F.; Ishaque, W.; Islam, M.A.; Shelia, V.; Awais, M.; Ullah, A.; et al Application of CSM-CROPGRO-Cotton model for cultivars and optimum planting dates: Evaluation in changing semi-arid climate. Field Crops Res. 2019, 238, 139-152. [CrossRef]

9. Gattoo, M.A.; Mustafa, G.; Iqbal, M. Impact of Farm Households' Adaptations to Climate Change on Food Security: Evidence from Different Agro-ecologies of Pakistan. Pak. Dev. Rev. 2016, 55, 561-588. [CrossRef]

10. Aslam, A.Q.; Ahmad, S.R.; Ahmad, I.; Hussain, Y.; Hussain, M.S. Vulnerability and impact assessment of extreme climatic event: A case study of southern Punjab, Pakistan. Sci. Total Environ. 2017, 580, 468-481. [CrossRef] [PubMed]

11. Imran, M.; Ali, A.; Ashfaq, M.; Hassan, S.; Culas, R.; Ma, C. Impact of Climate Smart Agriculture (CSA) Practices on Cotton Production and Livelihood of Farmers in Punjab, Pakistan. Sustainability 2018, 10, 2101. [CrossRef]

12. Raza, A.; Razzaq, A.; Mehmood, S.; Zou, X.; Zhang, X.; Lv, Y.; Xu, J. Impact of Climate Change on Crops Adaptation and Strategies to Tackle Its Outcome: A Review. Plants 2019, 8, 34. [CrossRef]

13. Jones, J.; Hoogenboom, G.; Porter, C.; Boote, K.; Batchelor, W.; Hunt, L.; Wilkens, P.; Singh, U.; Gijsman, A.; Ritchie, J. The DSSAT cropping system model. Eur. J. Agron. 2003, 18, 235-265. [CrossRef]

14. Hoogenboom, G.; Porter, C.H.; Boote, K.J.; Shelia, V.; Wilkens, P.W.; Singh, U.; White, J.W.; Asseng, S.; Lizaso, J.I.; Moreno, L.P.; et al. The DSSAT crop modeling ecosystem. In Advances in Crop Modeling for a Sustainable Agriculture; Boote, K.J., Ed.; Burleigh Dodds Science Publishing: Cambridge, UK, 2019; pp. 173-216. [CrossRef]

15. Hoogenboom, G.; Porter, C.H.; Shelia, V.; Boote, K.J.; Singh, U.; White, J.W.; Hunt, L.A.; Ogoshi, R.; Lizaso, J.I.; Koo, J.; et al. Decision Support System for Agrotechnology Transfer (DSSAT) Version 4.7.5; DSSAT Foundation: Gainesville, FL, USA, 2019; Available online: https: / DSSAT.net (accessed on 21 September 2021).

16. Thorp, K.R.; Barnes, E.M.; Hunsaker, D.J.; Kimball, B.A.; White, J.W.; Nazareth, V.J.; Hoogenboom, G. Evaluation of CSMCROPGRO-cotton for simulating effects of management and climate change on cotton growth and evapotranspiration in an arid environment. Trans. ASABE 2014, 57, 1627-1642. [CrossRef]

17. Shin, D.W.; Cocke, S.; Baigorria, G.A.; RomeroFFS, C.C.; Kim, B.-M.; Kim, K.-Y. Future Crop Yield Projections Using a Multi-model Set of Regional Climate Models and a Plausible Adaptation Practice in the Southeast United States. Atmosphere 2020, 11, 1300. [CrossRef]

18. Gul, F.; Ahmed, I.; Ashfaq, M.; Jan, D.; Fahad, S.; Li, X.; Wang, D.; Fahad, M.; Fayyaz, M.; Shah, S.A. Use of crop growth model to simulate the impact of climate change on yield of various wheat cultivars under different agro-environmental conditions in Khyber Pakhtunkhwa, Pakistan. Arab. J. Geosci. 2020, 13, 112. [CrossRef]

19. Elias, E.H.; Flynn, R.; Idowu, O.J.; Reyes, J.; Sanogo, S.; Schutte, B.J.; Smith, R.; Steele, C.; Sutherland, C. Crop vulnerability to weather and climate risk: Analysis of interacting systems and adaptation efficacy for sustainable crop production. Sustainability 2019, 11, 6619. [CrossRef]

20. Anser, M.K.; Hina, T.; Hameed, S.; Nasir, M.H.; Ahmad, I.; ur Rehman Naseer, M.A. Modeling Adaptation Strategies against Climate Change Impacts in Integrated Rice-Wheat Agricultural Production System of Pakistan. Int. J. Environ. Res. Public Health 2020, 17, 2522. [CrossRef]

21. Tolomio, M.; Casa, R. Dynamic crop models and remote sensing irrigation decision support systems: A review of water stress concepts for improved estimation of water requirements. Remote Sens. 2020, 23, 3945. [CrossRef]

22. Yan, W.; Jiang, W.; Han, X.; Hua, W.; Yang, J.; Luo, P. Simulating and Predicting Crop Yield and Soil Fertility under Climate Change with Fertilizer Management in Northeast China Based on the Decision Support System for Agrotechnology Transfer Model. Sustainability 2020, 12, 2194. [CrossRef] 
23. Hatfield, J.L.; Dold, C. Water-use efficiency: Advances and challenges in a changing climate. Front. Plant Sci. 2019, 10, 103. [CrossRef]

24. Modala, N.R.; Ale, S.; Rajan, N.; Munster, C.L.; DeLaune, P.B.; Thorp, K.R.; Nair, S.S.; Barnes, E.M. Evaluation of the CSMCROPGRO-Cotton Model for the Texas Rolling Plains Region and Simulation of Deficit Irrigation Strategies for Increasing Water Use Efficiency. Trans. ASABE 2015, 685-696. [CrossRef]

25. Adhikari, P.; Gowda, P.H.; Marek, G.W.; Brauer, D.K.; Kisekka, I.; Northup, B.; Rocateli, A. Calibration and Validation of CSM-CROPGRO-Cotton Model Using Lysimeter Data in the Texas High Plains. J. Contemp. Water Res. Educ. 2017, 162, 61-78. [CrossRef]

26. Hunt, L.A.; Pararajasingham, S.; Jones, J.W.; Hoogenboom, G.; Imamura, D.T.; Ogoshi, R.M. GENCALC: Software to Facilitate the Use of Crop Models for Analyzing Field Experiments. Agron. J. 1993, 85, 1090-1094. [CrossRef]

27. Wallach, D.; Goffinet, B. Mean squared error of prediction as a criterion for evaluating and comparing system models. Ecol. Modell. 1989, 44, 299-306. [CrossRef]

28. Willmott, C.J. Some Comments on the Evaluation of Model Performance. Bull. Am. Meteorol. Soc. 1982, 63, 1309-1313. [CrossRef]

29. Rawls, W.J.; Brakensiek, D.L.; Saxtonn, K.E. Estimation of Soil Water Properties. Trans. ASAE 1982, 25, 1316-1320. [CrossRef]

30. Taylor, K.E.; Stouffer, R.J.; Meehl, G.A. An Overview of CMIP5 and the Experiment Design. Bull. Am. Meteorol. Soc. 2012, 93, 485-498. [CrossRef]

31. Ruane, A.C.; Goldberg, R.; Chryssanthacopoulos, J. Climate forcing datasets for agricultural modeling: Merged products for gap-filling and historical climate series estimation. Agric. For. Meteorol. 2015, 200, 233-248. [CrossRef]

32. Rosenzweig, C.; Jones, J.W.; Hatfield, J.L.; Antle, J.M.; Ruane, A.C.; Mutter, C.Z. The Agricultural Model Intercomparison and Improvement Project: Phase I Activities by a Global Community of Science. In Handbook of Climate Change and Agroecosystems: The Agricultural Model Intercomparison and Improvement Project (Agmip) Integrated Crop and Economic Assessments-Joint Publication with Asa, Cssa, And Sssa (In 2 Parts); GISS Publications: New York, NY, USA, 2015; Volume 3, p. 1.

33. Pedreira, B.C.; Pedreira, C.G.S.; Boote, K.J.; Lara, M.A.S.; Alderman, P.D. Adapting the CROPGRO perennial forage model to predict growth of Brachiaria brizantha. Field Crops Res. 2011, 120, 370-379. [CrossRef]

34. Ortiz, B.V.; Hoogenboom, G.; Vellidis, G.; Boote, K.; Davis, R.F.; Perry, C. Adapting the CROPGRO-cotton model to simulate cotton biomass and yield under southern root-knot nematode parasitism. Trans. ASABE 2009, 52, 2129-2140. [CrossRef]

35. Malik, W.; Boote, K.J.; Hoogenboom, G.; Cavero, J.; Dechmi, F. Adapting the CROPGRO Model to Simulate Alfalfa Growth and Yield. Agron. J. 2018, 110, 1777-1790. [CrossRef]

36. Wajid, A.; Ahmad, A.; Khaliq, T.; Alam, S.; Hussaun, A.; Hussain, K.; Naseem, W.; Usman, M.; Ahmad, S. Quantification of growth, yield and radiation use efficiency of promising cotton cultivars at varying nitrogen levels. Pak. J. Bot. 2010, 42, 1703-1711.

37. San José, R.; Pérez, J.L.; González, R.M.; Pecci, J.; Garzón, A.; Palacios, M. Impacts of the 4.5 and 8.5 RCP global climate scenarios on urban meteorology and air quality: Application to Madrid, Antwerp, Milan, Helsinki and London. J. Comput. Appl. Math. 2016, 293, 192-201. [CrossRef]

38. Abadie, L.M.; Jackson, L.P.; Sainz de Murieta, E.; Jevrejeva, S.; Galarraga, I. Comparing urban coastal flood risk in 136 cities under two alternative sea-level projections: RCP 8.5 and an expert opinion-based high-end scenario. Ocean Coast. Manag. 2020, 193, 105249. [CrossRef] 